Review

\title{
Phase Transfer Catalysts and Role of Reaction Environment in Nucleophilc Radiofluorinations in Automated Synthesizers
}

\author{
Raisa N. Krasikova*(D) and Viktoriya V. Orlovskaya
}

check for updates

Citation: Krasikova, R.N.; Orlovskaya, V.V. Phase Transfer Catalysts and Role of Reaction Environment in Nucleophilc Radiofluorinations in Automated Synthesizers. Appl. Sci. 2022, 12, 321. https://doi.org/10.3390/app12010321

Academic Editors: Peter Laverman, Benjamin Guillet, Stefano Fanti and Qi-Huang Zheng

Received: 18 November 2021 Accepted: 28 December 2021 Published: 29 December 2021

Publisher's Note: MDPI stays neutral with regard to jurisdictional claims in published maps and institutional affiliations.

Copyright: (C) 2021 by the authors. Licensee MDPI, Basel, Switzerland. This article is an open access article distributed under the terms and conditions of the Creative Commons Attribution (CC BY) license (https:// creativecommons.org/licenses/by/ $4.0 /)$.
N.P. Bechtereva Institute of the Human Brain, Russian Academy of Sciences, 197376 Saint-Petersburg, Russia; orlovskaya@ihb.spb.ru

* Correspondence: raisa@ihb.spb.ru

\begin{abstract}
Incorporation of $\left[{ }^{18} \mathrm{~F}\right]$ fluorine into PET radiotracer structure has traditionally been accomplished via nucleophilic pathways. The $\left[{ }^{18} \mathrm{~F}\right]$ fluoride is generated in an aqueous solution via proton irradiation of oxygen-18 enriched water and must to be introduced into water-free organic solutions in order to generate reactive species. Thus nucleophilic ${ }^{18} \mathrm{~F}$-fluorination traditionally included steps for $\left[{ }^{18} \mathrm{~F}\right]$ fluoride concentration on the anion exchange resin, followed by removal of residual water via azeotropic distillation with $\mathrm{MeCN}$, a time-consuming process associated with radioactivity losses and difficult automation. To circumvent this, several adsorption/elution protocols were developed based on the minimization of water content in traditional kryptofix-based $\left[{ }^{18} \mathrm{~F}\right]$ fluoride eluents. The use of pre-dried $\mathrm{KOH} / \mathrm{kryptofix}$ solutions, tertiary alcohols, and strong organic bases was found to be effective. Advances in transition metal-mediated $\mathrm{S}_{\mathrm{N}} \mathrm{Ar}$ approaches for radiolabeling of non-activated aromatic substrates have prompted development of alternative techniques for reactive $\left[{ }^{18} \mathrm{~F}\right]$ fluoride species generation, such as organic solutions of non-basic alkyl ammonium and pyridinium sulfonates, etc. For radiofluorinations of iodonium salts precursors, a "minimalist" approach was introduced, avoiding the majority of pitfalls common to more complex methods. These innovations allowed the development of new time-efficient and convenient work-up procedures that are easily implementable in modern automated synthesizers. They will be the subject of this review.
\end{abstract}

Keywords: $\left[{ }^{18} \mathrm{~F}\right]$ fluoride; nucleophilc fluorinations; phase transfer catalysts; tetraalkylammonium salts; copper-mediated fluorination; synthesis automation

\section{Introduction}

Positron Emission Tomography (PET) is an important molecular imaging modality that has long been used for clinical diagnostics, particularly in the field of oncology. It allows quantification of physiological and pathological processes in living subjects on a molecular level through detection of radiotracer-biologically active or drug-like molecule labeled with positron-emitting radionuclides-biodistribution. Among cyclotron-produced radionuclides, ${ }^{11} \mathrm{C},{ }^{13} \mathrm{~N}$, and ${ }^{15} \mathrm{O}$, the ${ }^{18} \mathrm{~F}$ possesses the longest half-life $(109.8 \mathrm{~min})$ and favorable physicochemical and nuclear properties. Low positron energy of $0.635 \mathrm{MeV}$ allows for highest theoretical spatial resolution due to the shortest maximum range of positrons in tissue $(2.4 \mathrm{~mm}$ in water). Over $300 \mathrm{GBq}$ per batch of the radionuclide can be easily produced in a low-to-medium energy cyclotron via the ${ }^{18} \mathrm{O}(\mathrm{p}, \mathrm{n}){ }^{18} \mathrm{~F}$ reaction occurring during proton irradiation of ${ }^{18} \mathrm{O}$-enriched water in a high pressure target [1]. With this production approach, starting $\left[{ }^{18} \mathrm{~F}\right]$ fluoride and corresponding labeled tracers are available in high molar activity $\left(\mathrm{A}_{\mathrm{m}}\right)$ allowing for microdosing approach in receptorsbinding studies. Ca. 2-h half-life permits complex synthetic approaches, providing access to a large variety of ${ }^{18} \mathrm{~F}$-labeled radiopharmaceuticals (RPs) and also allows shipping of multiple clinical doses from a centralized production site to hospitals without access to cyclotron and radiochemistry/radiopharmacy facilities.

$\left[{ }^{18} \mathrm{~F}\right]$ fluoride is currently the most practical and generally available source of this radionuclide, and in this form, it is used in the vast majority of the ${ }^{18} \mathrm{~F}$-labeling procedures. 
Nucleophilic substitution of an appropriate leaving group in a precursor molecule with $\left[{ }^{18} \mathrm{~F}\right]$ fluoride is the most prominent method for the production of a variety of clinically relevant radiotracers [2-5]. $\left[{ }^{18} \mathrm{~F}\right]$ fluoride generated in a water target as strongly hydrated anion is generally unreactive in nucleophilic substitution scenarios. Therefore, the preprocessing steps are required to isolate $\left[{ }^{18} \mathrm{~F}\right] \mathrm{F}^{-}$from an aqueous environment and transform it into a reactive nucleophile species.

Early work on the nucleophilic ${ }^{18} \mathrm{~F}$-fluorinations included the removal of the bulk target water (1-3 mL volumes) by thermal distillation in the presence of $\mathrm{K}_{2} \mathrm{CO}_{3}$, added to prevent the formation of gaseous $\left[{ }^{18} \mathrm{~F}\right] \mathrm{HF}$. Following it up with azeotropic distillation with acetonitrile allowed for complete removal of residual water, however, the whole procedure was lengthy and generally impractical. Alternatively, separation of the $\left[{ }^{18} \mathrm{~F}\right]$ fluoride from $\left[{ }^{18} \mathrm{O}\right] \mathrm{H}_{2} \mathrm{O}$ (allowing for recycling of enriched water) on a strong anion-exchange cartridge (AEC) was introduced [6] and was found to be ideally suited for processing ${ }^{18} \mathrm{~F}^{-}$with implementation in the commercial automated synthesizers following shortly [7-9]. The recovery process is composed of two steps: the trapping of radionuclide on the resin and elution of adsorbed radioactivity with an organic-aqueous solution containing a base and a phase-transfer catalyst (PTC), most commonly the combination of $\mathrm{K}_{2} \mathrm{CO}_{3}$ and a cryptand (Kryptofix, $\mathrm{K}_{2 \cdot 2 \cdot 2}$, Sigma-Aldrich, St. Louis, Missouri, United States). The addition of cryptand enables solubilization of the $\left[{ }^{18} \mathrm{~F}\right]$ fluoride in a polar aprotic solvent and enhances nucleophilicity of the fluoride ion. The first application of $K_{2.2 .2}$. as cryptand in a ${ }^{18}$ F-radiolabeling was reported in 1986 for aliphatic nucleophilic synthesis of a fatty acid [10]; soon after, it was employed in the synthesis of 2-deoxy-2-[ ${ }^{18}$ F]fluoro-D-glucose ([$\left.\left.{ }^{18} \mathrm{~F}\right] \mathrm{FDG}\right)[11]$, the most commonly used fluorine-18 radiotracer. Following this formative work, a radiolabeling method using azeotropically dried $\left[{ }^{18} \mathrm{~F}\right] \mathrm{KF} / \mathrm{K}_{2.2 .2}$. $/ \mathrm{K}_{2} \mathrm{CO}_{3}$ was used in the preparation of a great variety of radiotracers for clinical and research applications in both aliphatic and aromatic nucleophilic substitution scenarios [2-5,12]. As an alternative to $\mathrm{K}_{2.2 .2}$. $/ \mathrm{K}_{2} \mathrm{CO}_{3}\left(\mathrm{KHCO}_{3}\right)$, tetrabutyl ammonium bicarbonate $\left(\mathrm{Bu}_{4} \mathrm{NHCO}_{3}\right)$ was introduced at about the same time [13] for solubilization of $\left[{ }^{18} \mathrm{~F}\right]$ fluoride, and, due to its lower basicity, was found to be effective in a number of nucleophilic fluorinations.

Since the presence of water severely reduces the reactivity of the fluoride ion in nucleophilic substitution reactions, trace water from the eluent mixture need to be carefully removed. Customarily this is achieved through a multi-step azeotropic drying process with the addition of several aliquots of acetonitrile. Although this procedure was implemented in most of the currently available commercial synthesis modules, the efficiency of drying depends on the reactor vessel design, heat transfer, vacuum/drying gas flow, and time. Incomplete drying strongly (and negatively) affects the reactivity of the $\left[{ }^{18} \mathrm{~F}\right]$ fluoride, drastically reducing yields. As a whole, the azeotropic drying step is time-consuming (6-15 $\mathrm{min}$ ) and is usually associated with significant losses of radioactivity due to decay and absorption of the radionuclide on the inner surfaces of the reaction vessel.

Another limitation of this approach is the use of the substantial amounts of the base to facilitate elution of $\left[{ }^{18} \mathrm{~F}\right]$ fluoride retained on the standard large-size anion exchange cartridges (Sep-Pak Plus QMA Light, $\mathrm{PSHCO}_{3}$ ). A typical kryptofix-based eluent contains 2.0-3.5 mg (15-25 $\mu \mathrm{mol})$ of $\mathrm{K}_{2} \mathrm{CO}_{3}$, which is an unacceptably large amount when dealing with base-sensitive precursors. Resulting basic reaction conditions often lead to the formation of undesired radiolabeled by-products and the generation of chemical impurities resulting from the decomposition of the precursor.

In order to address these issues, considerable efforts have been expended to develop

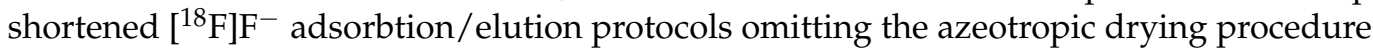
and, more importantly, providing less basic and milder ${ }^{18} \mathrm{~F}$-fluorination conditions for basesensitive precursors. A number of innovative methods and techniques were introduced by different groups through optimization of the base and phase-transfer agent used, eluting solvent composition, cartridge conditioning solvent (anion), and other parameters. As a result, a number of fine-tuned protocols for the preparation of particular radiotracers have been developed and published. 
In this review, our focus is on the improvement of "classical" methods for the activation of $\left[{ }^{18} \mathrm{~F}\right]$ fluoride facilitating their implementation into the routine automated production of radiotracers, as well as emerging methodologies and techniques. One needs to acknowledge that in recent years a number of microfluidic and microscale approaches have been introduced for small-scale production. However, they, as well as electrochemical methods used for reprocessing of $\left[{ }^{18} \mathrm{~F}\right]$ fluoride, lie outside of the scope of the current review.

\section{2. $\left[{ }^{18}\right.$ F $]$ Fluoride Activation for Aliphatic Nucleophilic $\mathrm{S}_{\mathrm{N}} 2$ Substitution}

Aliphatic nucleophilic $\mathrm{S}_{\mathrm{N}} 2$ substitution in the presence of $\mathrm{K}_{2.2 .2}$. $/ \mathrm{K}_{2} \mathrm{CO}_{3}$ or $\mathrm{Bu}_{4} \mathrm{NHCO}_{3}$ is currently the most prominent method for the production of the majority of clinically relevant radiotracers, including $\left[{ }^{18} \mathrm{~F}\right] \mathrm{FDG}, 3$-deoxy-3- $\left[{ }^{18} \mathrm{~F}\right]$ fluorothymidine $\left(\left[{ }^{18} \mathrm{~F}\right] \mathrm{FLT}\right)$, $\left[{ }^{18} \mathrm{~F}\right]$ fluoromisonidazole (1-[ $\left.{ }^{18} \mathrm{~F}\right]$ fluoro-3-(2-nitroimidazol-1-yl)-propan-2-ol; $\left.\left[{ }^{18} \mathrm{~F}\right] \mathrm{FMISO}\right)$, $O-\left(2^{\prime}-\left[{ }^{18} \mathrm{~F}\right]\right.$ fluoroethyl-L-tyrosine $\left(\left[{ }^{18} \mathrm{~F}\right] \mathrm{FET}\right), 16 \alpha-\left[{ }^{18} \mathrm{~F}\right]$ fluoroestradiol $\left(\left[{ }^{18} \mathrm{~F}\right] \mathrm{FES}\right)$ (Figure 1$)$, and others [2,5-12].
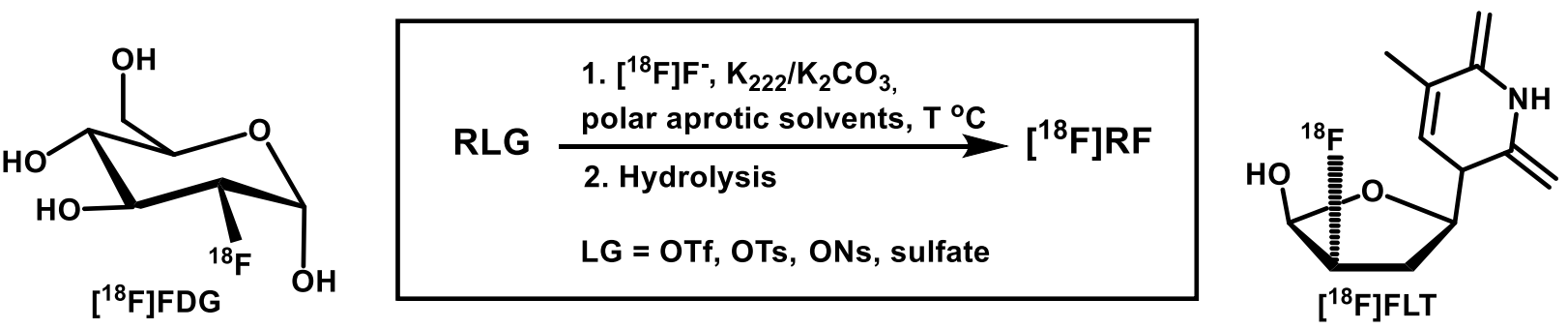

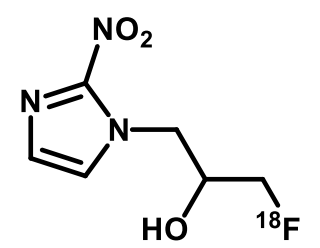

$\left[{ }^{18} \mathrm{~F}\right]$ FMISO<smiles>N[C@@H](Cc1ccc(OCCF)cc1)C(=O)O</smiles>

$\mathrm{HO}$<smiles>C[C@]12CC[C@@]3(C)c4ccc(O)cc4CC[C@]3(C)[C@@H]1C[C@H]([18F])[C@@H]2O</smiles>

Figure 1. The structures of the commonly used tumor seeking agents prepared by conventional aliphatic radiofluorination.

Typical one-vessel two-step synthesis of a radiotracer is achieved by nucleophilic displacement of an appropriate leaving group in the precursor with activated $\left.{ }^{18} \mathrm{~F}\right] \mathrm{F}^{-}$in polar aprotic solvents (MeCN, DMF, DMSO, etc.) at $80-130{ }^{\circ} \mathrm{C}$ followed by (if necessary) removal of the protective groups. This methodology was also adapted to the labeling of a number of ${ }^{18} \mathrm{~F}$-labeled bioactive and drug-like molecules prepared via direct radiofluorination, as well as for the preparation of the most common ${ }^{18} \mathrm{~F}$-fluoroalkylating agents [14] and prosthetic groups [15] for indirect radiolabeling approaches. Despite the fact that conventional azeotropic-drying methodologies are well established in the aliphatic fluorinations and are implemented in the majority of automated synthesizers, the drying-free approaches have shown distinct advantages such simplicity of the automation and shorter production time.

Traditionally the methods to circumvent the drying process relied upon the variation of the composition of kryptofix-based AEC eluent containing either $\mathrm{K}_{2} \mathrm{CO}_{3}$ or less basic $\mathrm{KHCO}_{3}, \mathrm{~K}_{2} \mathrm{C}_{2} \mathrm{O}_{4}$, and reduction of water fraction in the organic/water mixture. For basesensitive precursors encouraging results were achieved using chemically inert quaternary ammonium salts such as $\mathrm{Bu}_{4} \mathrm{NOTs}, \mathrm{Bu}_{4} \mathrm{NOTf}$, and $\mathrm{Et}_{4} \mathrm{NOTf}$ that have been introduced recently in lieu of "classical" $\mathrm{Bu}_{4} \mathrm{NHCO}_{3}$. 


\subsection{Azeotropic Drying Free Methods for Kryptofix-Mediated Radiofluorinations}

In the majority of protocols for kryptofix-mediated fluorinations the AEC resin-bound $\left[{ }^{18} \mathrm{~F}_{\mathrm{F}} \mathrm{F}^{-}\right.$is eluted from the cartridge with a solution of $\mathrm{K}_{2.2 .2}$. $/ \mathrm{K}_{2} \mathrm{CO}_{3}$ dissolved in a mixture of organic solvent and water.

The type of anion-exchange cartridge and the amount of packing material substantially influence the efficacy of $\left[{ }^{18}{\mathrm{~F}] \mathrm{F}^{-}}^{-}\right.$elution as well as the subsequent radiolabeling. Currently, the capture-and-release process is usually accomplished using standard Accell ${ }^{\mathrm{TM}}$ Plus QMA light Sep-Pak cartridge (filled with $130 \mathrm{mg}$ of quaternary ammonium chloride poly-

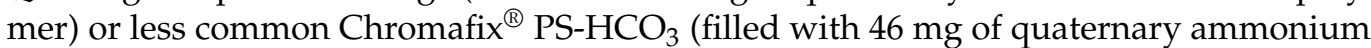
bicarbonate polymer). Before use, the $\mathrm{QMA}^{*} \mathrm{Cl}^{-}$cartridge is conditioned with aqueous $\mathrm{K}_{2} \mathrm{CO}_{3}$ or $\mathrm{KHCO}_{3}$ and water, while the $\mathrm{PSHCO}_{3}$ cartridge is just wetted with water. The QMA resin is also available in a carbonate form, the Sep-Pak Light (46 mg) Accel ${ }^{\mathrm{TM}}$ Plus QMA Carbonate cartridge that can be used as is, without any conditioning. These cartridges are used in all types of automated synthesizers as components of pre-assembled disposable cassettes (GE FASTlab) or the appropriate reagents kits (IBA Synthera). Barrel-type cartridges such as Vac QMA $1 \mathrm{cc}(100 \mathrm{mg})$, Oasis WAX $1 \mathrm{cc}$ Vac Cartridge (30 mg), Strata ${ }^{\mathrm{TM}}$ XL-A polymeric strong anion, $100 \mathrm{mg} / 3 \mathrm{~mL}$, and others are commonly encountered in research and development situations but are less common in routine applications.

Choosing the right eluent solvent mixture can significantly reduce drying time later on. A $100 \%$ aqueous eluent employed in the first published methods provided $100 \%$ elution efficiency (EE). However, the azeotropic drying time was too long for the method to be of significant practical use. In the current practice, the acetonitrile-water mixtures with different percentages of water are employed to shorten the drying procedure. Using eluent that contains only $4 \%$ of water and $96 \%$ of acetonitrile allowed for the dried reactive $\left[\mathrm{K} / \mathrm{K}_{2.2 .2 .}\right]^{+}\left[{ }^{18} \mathrm{~F}\right]^{-}$complex to be obtained without further addition of acetonitrile. According to this protocol, the radionuclide is trapped on a standard strong anion-exchange cartridge Accell ${ }^{\mathrm{TM}}$ Plus QMA light Sep-Pak $(130 \mathrm{mg})$ pre-conditioned with $10 \mathrm{~mL}$ of $0.5 \mathrm{M}$ $\mathrm{K}_{2} \mathrm{CO}_{3}$ solution and water, each. Trapped $\left.{ }^{18} \mathrm{~F}\right]$ fluoride is eluted with $2 \mathrm{~mL}$ of MeCN/ $\mathrm{H}_{2} \mathrm{O}$ $(96 / 4 \mathrm{v} / \mathrm{v})$ mixture containing $9.8 \mathrm{mg}(25 \mu \mathrm{mol})$ of $\mathrm{K}_{2.2 .2}$ and $1.8 \mathrm{mg}(12 \mu \mathrm{mol})$ of $\mathrm{K}_{2} \mathrm{CO}_{3}$, with $\mathrm{EE}>98 \%$. Evaporation of solvents at $110{ }^{\circ} \mathrm{C}$ under a stream of nitrogen (with no vacuum) produces reactive $\left[{ }^{18} \mathrm{~F}\right]$ fluoride directly. The general applicability of this methodology, originally developed by our group for automated synthesis of $\left[{ }^{18} \mathrm{~F}\right] \mathrm{FDG}[16,17]$, was confirmed by applying it to the routine preparations of the tumor imaging agents

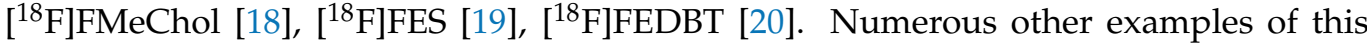
method's application to production of other radiotracers were reported in the literature: $\left[{ }^{18}\right.$ F]Flumazenil [21], [ ${ }^{18}$ F]FEPE2I [22], [ ${ }^{18}$ F]FP-06684511 [23], [ ${ }^{18}$ F]MCL524 [24], and others [Figure 2].

Pascali and co-authors $[25,26]$ have reported an azeotropic-drying free method using QMA eluent containing $12 \%$ of water in acetonitrile with less basic $\mathrm{KHCO}_{3}$. The $\left[{ }^{18} \mathrm{~F}^{-} \mathrm{F}^{-}\right.$ retained on the cartridge (QMA, $130 \mathrm{mg}$ ) was eluted with $1 \mathrm{~mL}$ of $\mathrm{K}_{2.2 .2}$. $/ \mathrm{KHCO}_{3}$ solution; with vacuum-assisted evaporation to dryness at $72{ }^{\circ} \mathrm{C}$ under a nitrogen flow following, affording reactive $\left[{ }^{18} \mathrm{~F}\right]$ fluoride species. Using this protocol, two highly-sought radiotracers, $\left[{ }^{18} \mathrm{~F}\right] \mathrm{FET}[25]$ and $\left[{ }^{18} \mathrm{~F}\right] \mathrm{FMISO}$ [26] were synthesized. The latter one was obtained in greater radiochemical yield (RCY) (54\% against reported 30-40\% for conventional methods), with only $30 \mathrm{~min}$ total synthesis time.

However, even as techniques described [16-26] avoid azeotropic drying procedure, the eluting solvent must still be removed by distillation to be replaced with the reaction solvent. There has been a recent focus on developing methodologies with the aim of completely excluding the need for solvent replacement prior to radiofluorination step. 


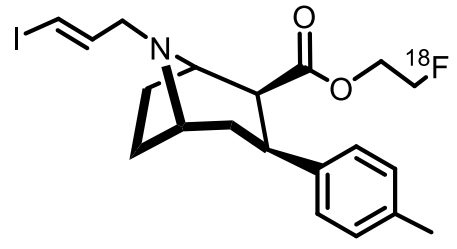

$\left[{ }^{18}\right.$ F]FEPE2<smiles>C=CCN1CCC[C@H]1NC(=C)c1cc(CCCF)cc(OC)c1OC</smiles>

$\left[{ }^{18}\right.$ F]Fallypride<smiles>COc1cnc(C(=O)Nc2ccc(F)c([C@]34CO[C@H](C[18F])[C@@H]3CSC(N)=N4)c2)cn1</smiles><smiles>CCCN1CCc2cc(OCC[18F])cc3c2[C@H]1Cc1ccc(O)c(O)c1-3</smiles><smiles>COc1ccc(OCC[18F])c(CN(C(C)=O)c2cc(F)ccc2Oc2ccccc2)c1</smiles>

$\left[{ }^{18}\right.$ F]FEDAA1106

Figure 2. The structures of PET brain radioligands prepared by aliphatic radiofluorination.

Wester and co-workers [27] described an approach using highly concentrated $\mathrm{K}_{2.2 .2 .} / \mathrm{KOH}$

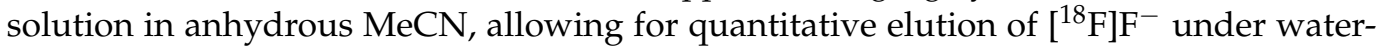
free conditions. No solvent evaporation was required to obtain reactive $\left[{ }^{18} \mathrm{~F}\right]$ fluoride species. The applicability of this methodology to the preparation of several well-known radiotracers $\left(\left[{ }^{18} \mathrm{~F}\right] \mathrm{FDG},\left[{ }^{18} \mathrm{~F}\right] \mathrm{FET},\left[{ }^{18} \mathrm{~F}\right] \mathrm{FLT},\left[{ }^{18} \mathrm{~F}\right] \mathrm{FAZA}\right.$, and $\left[{ }^{18} \mathrm{~F}\right]$ fallypride) was confirmed when radiolabeling was carried out using small aliquots of the eluate. An example of application of this so-called "Munich method" in a full-batch production is the synthesis of ${ }^{18}$ F-rhPSMA-7 [28], a novel hybrid PSMA radiloligand that contains either ${ }^{18} \mathrm{~F}$ or ${ }^{68} \mathrm{Ga}$ in the same structure. In a manual synthesis $[28]\left[{ }^{18} \mathrm{~F}^{\mathrm{F}} \mathrm{F}^{-}\right.$was eluted from the QMA cartridge $(46 \mathrm{mg})$ with a mixture of $\mathrm{K}_{2.2 .2}$. $(110 \mu \mathrm{mol})$ and $\mathrm{KOH}(100 \mu \mathrm{mol})$ in $0.5 \mathrm{~mL}$ of $\mathrm{MeCN}$; the eluent was freshly prepared from the lyophilized kit. The eluate was collected directly into a reaction vessel containing labeling precursor (50-150 nmol) and an oxalic acid (to provide less basic conditions [29]) in $150 \mu \mathrm{L} \mathrm{DMSO} / 30 \mu \mathrm{L} \mathrm{MeCN}$ mixture. Isotopic ${ }^{19} \mathrm{~F} /{ }^{18} \mathrm{~F}$ exchange reaction was completed in 5 min at r.t. providing an RCY of over $55 \%$ after cartridge-based purification. Despite the distinct advantages of this time-saving and easyto-automate protocol, it has not yet been implemented into routine ${ }^{18} \mathrm{~F}$-radiochemistry, possibly due to the need for high amounts of base and subsequently relatively large amount of precursors required.

Very recently [30] use of water-free eluent containing $\mathrm{KHCO}_{3}(1.6 \mathrm{mg})$ and $\mathrm{K}_{2.2 .2}$. $(6.0 \mathrm{mg})$ in $\mathrm{MeOH}(0.4 \mathrm{~mL})$ for the recovery of $\left[{ }^{18} \mathrm{~F}\right]$ fluoride from the QMA cartridge $(46 \mathrm{mg}$, carbonate form) followed by direct use of the eluate in labeling reaction has been reported. This methodology was previously developed [30] for microscale ${ }^{18} \mathrm{~F}$-radiolabeling with minimization of the amounts of base and cryptand. Synthesis of a ${ }^{18} \mathrm{~F}$-labeled stilbene [30] for $\beta$-amyloid imaging was achieved using $2 \mathrm{mg}$ of precursor in $0.2 \mathrm{~mL}$ of DMSO. When employing conventional azeotropic drying methodology for the same synthesis, a substantial amount of the unlabeled impurities in the reaction mixture was observed. The authors speculate that heating acetonitrile in the presence of $\mathrm{K}_{2} \mathrm{CO}_{3}$ and $\mathrm{K}_{2.2 .2}$. promoted dimerization of acetonitrile, leading to the formation of butyronitrile. The latter then reacted with the sulfonyl leaving group of the precursor producing unlabeled impurities. In contrast, no impurities were observed using the water-free methanolic solution in the elution stage with no need for azeotropic drying. Still, in this approach, the eluting solvent needs to be removed before fluorination. Noteworthy, this is the first report pointing out the possibility of MeCN dimerization under azeotropic drying conditions. Small volumes of the 
solvents employed in the method [31] might be a limitation of this approach's amenability to automation due to possible losses of the radioactivity in the transfer lines.

A relatively straightforward method [32] avoiding the need to remove the water is a kryptofix-mediated radiofluorination in a mixed organic solvent system containing only a small amount of water. Good tolerance to the presence of trace water was demonstrated in the preparation of three radiotracers, $\left[{ }^{18} \mathrm{~F}\right] \mathrm{PSS} 232,\left[{ }^{18} \mathrm{~F}\right] \mathrm{MISO}$, and $\left[{ }^{18} \mathrm{~F}\right]$ fallypride when using $\left[{ }^{18} \mathrm{~F}^{-} \mathrm{F}^{-}\right.$eluent containing $\mathrm{K}_{2.2 .2 .}(7.2 \mathrm{mg}, 19 \mu \mathrm{mol})$ and $\mathrm{K}_{2} \mathrm{CO}_{3}(1.3 \mathrm{mg}, 9.6 \mu \mathrm{mol})$ in

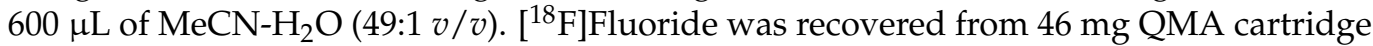
(EE 86\%) directly into a solution of the precursor in DMA; fluorination was carried out in DMA/MeCN (70/30) mixture containing $97 \mu \mathrm{L}$ of water. This operationally simple methodology was easily implemented on a GE TRACERlab FX FN platform (GE Healthcare, Madison, WI, USA) exemplified by the automated production of $\left[{ }^{18} \mathrm{~F}\right]$ fallypride, a clinically useful D2/D3 antagonist radioligand with a moderate RCY of $25 \%$.

In another report [33], eluate containing a certain amount of water (4850 ppm, eluted volume $1 \mathrm{~mL}$ ) was used directly in the radiolabeling of several aliphatic and aromatic precursors, including mannose triflate $\left(\left[{ }^{18} \mathrm{~F}\right] \mathrm{FDG}\right.$ precursor). To trap cyclotron-produced $\left[{ }^{18} \mathrm{~F}\right]$ fluoride a custom-prepared water-wettable macroporous co-polymer loaded with a long alkyl chain quaternary ammonium salt was used instead of the conventional QMA cartridge. Limitations of this methodology are the need for high precursor amounts (15-40 mg) and the necessity to add the additional PTCs, either $\mathrm{K}_{2} \mathrm{CO}_{3} / \mathrm{K}_{2.2 .2} .(7 \mathrm{mg} / 22 \mathrm{mg})$ or $\mathrm{Et}_{4} \mathrm{NHCO}_{3}(50 \mathrm{mg})$ to increase the fluorination efficiency. Noteworthy, since only an aliquot of the eluate was used in the radiofluorinations, the reaction conditions were effectively anhydrous. Due to the exclusion of the evaporation steps, this approach appears to be attractive for deployment in microfluidic systems, which was one of the goals of this study.

A successful aliphatic substitution reaction with $\left[{ }^{18} \mathrm{~F}\right]$ fluoride in the presence of $2-$ $3 \%$ of water (12.000-20.000 ppm) was demonstrated by Kniess and co-workers [34] in the azeotropic-drying free synthesis of $2-\left[{ }^{18} \mathrm{~F}\right]$ fluoroethyl tosylate, a frequently used ${ }^{18} \mathrm{~F}-$ fluorialkylating agent. With this so-called "hydrous fluoroethylation" protocol, $\left[{ }^{18} \mathrm{~F}\right] \mathrm{F}^{-}$ loaded onto the QMA cartridge was eluted with $0.7 \mathrm{~mL}$ of solution containing $21 \mu \mathrm{mol}$ $\mathrm{K}_{2} \mathrm{CO}_{3}$ and $42 \mu \mathrm{mol} \mathrm{K}_{2.2 .2 .}$; the collected eluate was used directly in reaction with 1,2ethylene glycol-bistosylate $(7 \mathrm{mg}, 19 \mu \mathrm{mol})$ with further one-pot ${ }^{18} \mathrm{~F}$-fluoroalkylation reaction promoted by $\mathrm{Cs}_{2} \mathrm{CO}_{3}$ as a base. Avoiding any solvent removal steps has resulted in five-fold increase in the isolated RCY of three model COX-2 inhibitors not only due to shortened synthesis procedure but also due to minimal losses of the radioactivity on the inner walls of the reaction vessel.

\subsection{Tetraalkylammonium Salts $\left(B u_{4} N^{+}, E t_{4} N^{+}\right)$as the PTCS}

Tetraalkylammonium salts together with basic, non-nucleophilic anions (e.g., $\mathrm{CO}_{3}{ }^{2-}$ or $\mathrm{HCO}_{3}{ }^{-}$) have been used for the years $[13,34]$ with $\mathrm{Bu}_{4} \mathrm{NHCO}_{3}$ as less basic alternatives to $\mathrm{K}_{2.2 .2}$. $/ \mathrm{K}_{2} \mathrm{CO}_{3}$. They are characterized by counter-ion exchanging ability with $\left[{ }^{18} \mathrm{~F}\right]$ fluoride and good solubility in most organic solvents. From this group of the PTCs, $\mathrm{Bu}_{4} \mathrm{NHCO}_{3}$ has been the most widely used, demonstrating higher [35,36] or similar [37] RCYs when compared to conventional kryptofix-mediated fluorinations. The $\left[{ }^{18} \mathrm{~F}^{-} \mathrm{F}^{-}\right.$is quantitatively recovered from the AEC with the eluent composed of $\mathrm{MeCN}(2 \mathrm{~mL})$ and $\mathrm{Bu}_{4} \mathrm{NHCO}_{3}$ ( $0.075 \mathrm{~mL}, 20 \%$ aq., $\mathrm{pH}$ 8) [38,39] followed by conventional azeotropic drying. Quite recently [38], an elution protocol using ethanolic solution of the PTC $\left(0.075 \mathrm{M} \mathrm{Bu}_{4} \mathrm{NHCO}_{3}\right.$ in $0.5 \mathrm{~mL}$ of $\mathrm{EtOH})$ was described. The reactive $\left[{ }^{18} \mathrm{~F}\right]$ fluoride species thus produced was further used for the synthesis of $\left[{ }^{18} \mathrm{~F}\right] \mathrm{FES}$ immediately after simple solvent evaporation without the need for azeotropic drying. For this radiotracer similar RCYs of around 50\% (decay-corrected) were obtained regardless of the choice of the PTC $-\mathrm{K}_{2.2 .2 .} / \mathrm{K}_{2} \mathrm{CO}_{3}$ or $\mathrm{Bu}_{4} \mathrm{NHCO}_{3}$.

Similar to $\mathrm{Bu}_{4} \mathrm{NHCO}_{3}$, tetraethylammonium salts were found to be effective in enhancing $\left[{ }^{18} \mathrm{~F}\right]$ fluoride reactivity in both aliphatic and aromatic nucleophilic substitution 
scenarios. Brichard and Aigbirhio [39] demonstrated that $\mathrm{Et}_{4} \mathrm{NHCO}_{3}(15 \mathrm{mg})$ dissolved in a polar aprotic solvent (MeCN, DMF, DMSO) containing up to $5 \%$ of water could be used to elute QMA-loaded $\left[{ }^{18} \mathrm{~F}^{-} \mathrm{F}^{-}\right.$with elution performed in the reverse (opposite to loading) direction. The obtained eluate can be used directly in further fluorinations eliminating solvents evaporation steps. The feasibility of this approach was confirmed for a wide range of the aliphatic substrates $\left(\left[{ }^{18} \mathrm{~F}\right] \mathrm{FDG},\left[{ }^{18} \mathrm{~F}\right]\right.$ fallypride, $\left.\left[{ }^{18} \mathrm{~F}\right] \mathrm{FEDAA} 1106\right)$ and model aromatic compound demonstrating similar or increased RCY when compared with conventional kryptofix-mediated procedures. However, it is worth noting that all the labeling reactions were performed using small aliquots of the eluate $(50-100 \mu \mathrm{L})$. Thus, the applicability of this methodology for full-batch production needs to be evaluated further, which reduces both the amount of base and the amount of water in the reaction mixture. Thus the applicability of this methodology for full-batch production needs to be evaluated further.

In general, in routine clinical application use of $\mathrm{Et}_{4} \mathrm{NHCO}_{3}$ is not as common as $\mathrm{Bu}_{4} \mathrm{NHCO}_{3}$. In one of the recent protocols [40] that has been implemented into GMP production of $\left[{ }^{18} \mathrm{~F}\right] \mathrm{DPA}-714$, preparation of reactive $\mathrm{Et}_{4} \mathrm{~N}^{+}\left[{ }^{18} \mathrm{~F}\right] \mathrm{F}^{-}$still incorporated steps for "traditional" solvent removal. Automated synthesis on a Trasis AllinOne (AIO) cassettebased module involved elution of the $\left[{ }^{18} \mathrm{~F}\right]$ fluoride from the QMA cartridge with a solution of $\mathrm{Et}_{4} \mathrm{NHCO}_{3}$ in water/acetonitrile $(85 / 15 \mathrm{v} / \mathrm{v})$, followed by azeotropic distillation. Fluorination of the corresponding tosyl precursor in MeCN provided significantly higher $\mathrm{RCY}$ (55-71\%) if compared with earlier kryptofix-based methods. The authors speculate that $\mathrm{Et}_{4} \mathrm{NHCO}_{3}$ could be a better enhancer of $\left[{ }^{18} \mathrm{~F}\right]$ fluoride nucleophilicity than $\mathrm{K}_{2.2 .2 .} / \mathrm{K}_{2} \mathrm{CO}_{3}$ or $\mathrm{K}_{2.2 .2} / \mathrm{KHCO}_{3}$, probably due to better stabilization of the precursor-fluoride intermediate during the reaction.

Apart from developments concerning the elimination of the azeotropic drying step and improvements in automation, considerable efforts have been directed at the control of the basicity of the reaction medium, with aim to reduce amount of precursors used in the reaction. Aliphatic radiofluorination of base-sensitive precursors has received much attention in particular. A recent review [41] summarises various new developments in this field. In particular, success [42-44] has been achieved by exploiting tetraalkylammonium salts in conjunctions with less basic anions such as mesylate, tosylate, and triflate. The first application of these quaternary ammonium salts $\left(\mathrm{Bu}_{4} \mathrm{NOMs}\right.$ and $\left.\mathrm{Bu}_{4} \mathrm{NOTf}\right)$ dates back to 2011 [45]. It was shown that the solution of $\mathrm{Bu}_{4} \mathrm{NOMs}$ in methanol $(0.6 \mathrm{~mL}, 10 \mathrm{mg}$ $(30 \mu \mathrm{mol})$ ) could release over $90 \%$ of the radioactivity from the AEC (Chromafix ${ }^{\circledR}$ PS$\mathrm{HCO}_{3}$ ) and provide over $90 \%$ RCC in the radiofluorination of model aliphatic substrates when carried out in tertiary alcohols. The effects induced by conditioning anion replacing bicarbonate ion in the $\mathrm{PSHCO}_{3}$ resin with other anionic bases such as $\mathrm{Na}_{2} \mathrm{CO}_{3}, \mathrm{~K}_{2} \mathrm{HPO}_{4}$, and $\mathrm{K}_{3} \mathrm{PO}_{4}$ was also examined in that study. It turned out that conditioning the cartridge with phosphate-based anions $\left(\mathrm{KHPO}_{4}{ }^{-}\right.$and $\left.\mathrm{K}_{2} \mathrm{PO}_{4}{ }^{-}\right)$did not only provide the highest RCC in radiofluorination of aliphatic substrates but contributed significantly to creating a mild reaction environment with unreacted precursor remaining almost intact.

Although that study demonstrated distinct advantages of $\mathrm{Bu}_{4} \mathrm{NOMs}$ as a neutral PTC, results obtained in fluorination of model compounds were not extended further to the preparation of clinically relevant radiopharmaceuticals. Thus with the aim of wider implementation of this concept our group has recently [42] suggested a general protocol where the use of the corresponding tosylate salt, $\mathrm{Bu}_{4} \mathrm{NOTs}$, was adapted to the routine automated synthesis of a series of ${ }^{18}$ F-labeled radiotracers $\left[{ }^{18} \mathrm{~F}\right] \mathrm{FDG},\left[{ }^{18} \mathrm{~F}\right] \mathrm{FLT}$, $\left[{ }^{18} \mathrm{~F}\right] \mathrm{FMISO}$, $\left[{ }^{18} \mathrm{~F}\right] \mathrm{FET},\left[{ }^{18} \mathrm{~F}\right] \mathrm{FES}$ as well as common radiolabeling synthon, $2-\left[{ }^{18} \mathrm{~F}\right]$ fluoroethyl tosylate ( $\left.\left[{ }^{18} \mathrm{~F}\right] \mathrm{FEOTs}\right)$. The radionuclide initially retained on a QMA cartridge (conditioned with an aq. $\left.\mathrm{KHCO}_{3}\right)$ was recovered in a solution of $\mathrm{Bu}_{4} \mathrm{NOTs}(1 \mathrm{mg}, 2.5 \mu \mathrm{mol})$ in $\mathrm{MeOH}$ or EtOH. Following solvent removal, reactive $\left[{ }^{18} \mathrm{~F}\right]$ fluoride was reconstituted in $1 \mathrm{~mL}$ of $\mathrm{MeCN}$. In order to achieve release of $\left[{ }^{18}{\mathrm{~F}] \mathrm{F}^{-}}^{-}\right.$from conventional $130 \mathrm{mg}$ QMA cartridge while using such a low amount of the PTC, a reversed loading/elution procedure was employed of the type that has been demonstrated in radiofluorination of electron-rich arenes [46]. However, in conjunction with a smaller QMA Light carbonate cartridge (46 mg) 
a straightforward eluting protocol was found to be just as effective in providing high EE using the same amount of $\mathrm{Bu}_{4} \mathrm{NOTs}$ dissolved in $2 \mathrm{~mL}$ of $\mathrm{EtOH}$. The radiofluorinations were carried out in $\mathrm{MeCN}$, a solvent commonly employed for the aliphatic fluorinations, under typical reaction conditions $\left(100^{\circ} \mathrm{C}, 10 \mathrm{~min}\right)$. High RCCs (70-95\%) were achieved using significantly reduced amounts $(0.2-1.2 \mathrm{mg} / 0.5-1.2 \mu \mathrm{mol})$ (Table 1$)$ of precursors compared to traditional approaches. In addition, by reducing the precursor amounts, the sources of chemical impurities in the final preparations are minimized, allowing for simplification of the purification procedures. The practical utility of the method (standard elution protocol, $46 \mathrm{mg}$ QMA cartridge) was demonstrated in automated synthesis of $\left[{ }^{18} \mathrm{~F}\right]$ FET [47], $\left[{ }^{18} \mathrm{~F}\right] \mathrm{FES}[48]$, and $\left[{ }^{18} \mathrm{~F}\right] \mathrm{FDG}$ [42] on the GE TRACERlab FX N Pro module, one of most common ${ }^{18} \mathrm{~F}$-labeling platform.

Table 1. The synthesis of radiotracers [42] via radiofluorination in the presence of $\mathrm{Bu}_{4} \mathrm{NOTs}(1 \mathrm{mg}$, $2.5 \mu \mathrm{mol}$ in $2 \mathrm{~mL}$ of EtOH, QMA carb, $46 \mathrm{mg}$ ); $\mathrm{MeCN}, 100^{\circ} \mathrm{C}, 10 \mathrm{~min}$; RCY-radiochemical yields, non-decay corrected.

\begin{tabular}{cccc}
\hline $\begin{array}{c}\text { Radiotracer } \\
\text { or Synthon }\end{array}$ & $\begin{array}{c}\text { Precursor Amount, } \\
\mathbf{m g} / \mu \mathbf{m o l}\end{array}$ & $\begin{array}{c}\text { RCC, } \% \\
\text { by TLC }(\boldsymbol{n}=\mathbf{3})\end{array}$ & $\begin{array}{c}\text { RCY (\%)/ } \\
\text { Synthesis Time, Min }\end{array}$ \\
\hline$\left[{ }^{18} \mathrm{~F}\right] \mathrm{FETs}$ & $0.2 / 0.5$ & $96 \pm 2$ & - \\
{$\left[{ }^{18} \mathrm{~F}\right] \mathrm{FDG}$} & $1.2 / 1.2$ & $91 \pm 1$ & $60 / 25[42]$ \\
{$\left[{ }^{18} \mathrm{~F}\right] \mathrm{FMISO}$} & $0.2 / 0.5$ & $74 \pm 1$ & - \\
{$\left[{ }^{18} \mathrm{~F}\right] \mathrm{FET}$} & $0.4 / 0.6^{*}$ & $83 \pm 1$ & - \\
{$\left[{ }^{18} \mathrm{~F}\right] \mathrm{FLT}$} & $2 / 0.3^{* *}$ & $93 \pm 4$ & $40 / 35[47]$ \\
{$\left[{ }^{18} \mathrm{~F}\right] \mathrm{FES}$} & $1 / 1.1$ & $65 \pm 4$ & - \\
\hline
\end{tabular}

* TET precursor, ABX [35], ** chiral nickel (II) complex [36].

To further explore the potential of tetraalkylammonium salts in respect to reaction basicity and resolubilization of the $\left[{ }^{18} \mathrm{~F}\right]$ fluoride, effects of three different salts $\mathrm{Bu}_{4} \mathrm{NOMs}_{\text {, }}$ $\mathrm{Bu}_{4} \mathrm{NOTf}$, and $\mathrm{Bu}_{4} \mathrm{NH}_{2} \mathrm{PO}_{4}$ were recently investigated by Bratteby and co-workers [43]. In model experiments, the key parameters evaluated were trapping of $\left[{ }^{18} \mathrm{~F}\right]$ fluoride on the standard QMA cartridge, its subsequent elution, and the effects of different conditioning regiments, which led to the identification of a number of relevant factors affecting RCC of the ${ }^{18} \mathrm{~F}^{-}$fluorination of base-sensitive precursors. Through testing of a great variety of combinations for conditioning and elution anions, suitable general protocols applicable to the synthesis of currently used radiotracers were developed.

In the following publication by the same group [49], the radiolabeling protocol for $\left[{ }^{18} \mathrm{~F}\right]$ FEE2I, a well-established dopamine transporter radioligand, was developed and implemented in a cassette-based Synthera ${ }^{\circledR}+$ HPLC (IBA) synthesizer. Despite the fact that a previous study [43] revealed the highest RCC (72.5 $\pm 13.1 \%)$ for [ $\left.{ }^{18} \mathrm{~F}\right] \mathrm{FEE} 2 \mathrm{I}$ was achieved in the presence of $\mathrm{Bu}_{4} \mathrm{NOMs}$, due to the potential toxicity of mesylate ions, the $\mathrm{Bu}_{4} \mathrm{NH}_{2} \mathrm{PO}_{4}$ was chosen for the clinical production implementation. For elution procedure, $20 \mu \mathrm{mol}$ of this PTC in $\mathrm{MeCN} / \mathrm{H}_{2} \mathrm{O}$ (50:50) was applied to the standard QMA cartridge pre-conditioned with $\mathrm{CO}_{3}{ }^{2-}$. The ${ }^{18} \mathrm{~F}^{-}$eluate was then concentrated to dryness via three short cycles of combined application of $\mathrm{N}_{2}$ flow and vacuum, resulting in the complete removal of the eluting solvent. Using DMSO as the reaction solvent, the product was obtained with the isolated RCY of $33 \pm 2 \%(n=3)$ from the $45 \mathrm{GBq}$ starting activity. Due to radiolysis, the synthesis with higher starting activities (up to $140 \mathrm{GBq}$ ) proceeded with the decrease in RCY even under optimal conditions.

In line with these studies [42,43], Inkster and co-workers [44] recently employed waterorganic solutions (up to $50 \%$ of water) of tetraethyl ammonium salts $\left(\mathrm{Et}_{4} \mathrm{NOTs}_{2} \mathrm{Et}_{4} \mathrm{NClO}_{4}\right)$ to recover $\left[{ }^{18} \mathrm{~F}^{-} \mathrm{F}^{-}\right.$that was trapped on an miniature MP-1 anion-exchange column or a commercial QMA anion-exchange column (both in carbonate form, 10-12 mg; MedChem Imaging, LLC, Boston, United States), commonly used in microfluidic synthesis. The elution was performed in reverse mode; the eluate was directly used for ${ }^{18} \mathrm{~F}$-substitution reactions, i.e., without any evaporation steps. The low volume of the concentrated eluent 
$\left(\mathrm{Et}_{4} \mathrm{NOTs}, 23.5 \mathrm{mg} / \mathrm{mL}, 100 \mu \mathrm{L}\right.$ in $7: 3 \mathrm{MeCN}: \mathrm{H}_{2} \mathrm{O}$ ) was sufficient to release radioactivity from the AEC. The eluate was mixed with the precursor solution in $900 \mu \mathrm{L}$ of MeCN with a final reaction volume equal to $1 \mathrm{~mL}$ with $3 \%$ water. The radiofluorinations were carried out with microwave heating $\left(150^{\circ} \mathrm{C}, 10 \mathrm{~min}\right)$, showing high $\mathrm{RCC}$ in the synthesis of $\left[{ }^{18} \mathrm{~F}\right]$ fallypride, a widely used $\mathrm{D}_{2} / \mathrm{D}_{3}$ antagonist tracer, on a sub-hundred-MBq scale. More recently [50] this protocol was employed in a small scale $\left(190-225 \mathrm{MBq}\right.$ of $\left.\left[{ }^{18} \mathrm{~F}\right] \mathrm{F}^{-}\right)$manual synthesis of $\left[{ }^{18} \mathrm{~F}\right] \mathrm{MCL}-524, \mathrm{D}_{2}$ agonist moderately selective for the high-affinity state of the $\mathrm{D}_{2}$ receptor. Despite the RCC of radiofluorination of the precursor being high (ca. 50\%), due to lengthy procedure of deprotection with $\operatorname{In}(\mathrm{OTf})_{3}$ and HPLC purification, the RCY of 5-9\% (decay corrected) was obtained (with synthesis time of 146-199 min) providing enough $\left[{ }^{18} \mathrm{~F}\right] \mathrm{MCL}-524$ for preclinical imaging applications.

This proof-on-concept study supports the conjecture that non-basic tetraalkylammonium salts could serve as the PTCs in non-anhydrous solvent mixtures where no solvent removal steps would be required to produce reactive $\left[{ }^{18} \mathrm{~F}\right] \mathrm{F}^{-}$species. However, to serve as a useful production method, the manual protocol $[49,50]$ developed with its use of miniature anion-exchange columns, small eluent volumes as well as microwave heating, needs to be adapted to commercial synthesizers with conventional heaters and employing "normal size" AEC for scalable radionuclide processing.

\subsection{PTC Free Cartridge-Based Radiofluorination of Aliphatic Substrates}

In principle, immobilizing precursor on the solid-phase support to perform an online ${ }^{18} \mathrm{~F}$-fluorination avoiding $\left[{ }^{18} \mathrm{~F}\right] \mathrm{F}^{-}$elution, azeotropic evaporation, and PTC additions is a hugely attractive concept. It was successfully applied as early as 1990 [51] in the synthesis of $\left[{ }^{18} \mathrm{~F}\right] \mathrm{FDG}$ via resin-based nucleophilic ${ }^{18} \mathrm{~F}$-fluorination of mannose triflate, using a quaternary 4 -( $N, N$-dialkylamino)-pyridinium functionalized polystyrene anion-exchange resin ("4-AP" resin) as solid support. [ $\left.{ }^{18} \mathrm{~F}\right]$ fluoride was captured on a small resin-packed column. The column was then dried by rinsing it with anhydrous $\mathrm{MeCN}$, and the solution of mannose triflate was slowly pushed through the column heated to $100{ }^{\circ} \mathrm{C}$. Labeled intermediate was then eluted into reaction vessel for removal of acetyl protecting groups through acidic hydrolysis. This procedure was implemented in the first cassette-based synthesizer (FDG Microlab, GE Medical Systems, Uppsala, Sweden) for routine productions of $\left[{ }^{18} \mathrm{~F}\right] \mathrm{FDG}$ [52]. Due to the issues with the manually-packed "4-AP" resin columns that had to be stored in methanol and other technical issues, the manufacture, and supply of the cassettes and FDG Microlab modules were seized around 2005.

Alternatively, [53] the use of commercially available polymer-supported phosphazene base PS- $\mathrm{P}_{2}{ }^{\mathrm{tBu}}$ was found to be effective for resin-based ${ }^{18} \mathrm{~F}$-fluorinations of a series of aliphatic substrates. The phosphazene super bases such as $\mathrm{P}_{2}{ }^{\mathrm{Et}}$ were earlier introduced by

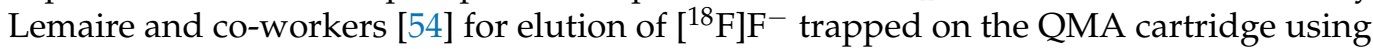
acetonitrile containing carefully controlled amounts of water ( $1 \mathrm{~mL} \mathrm{MeCN}, 5-10,000 \mathrm{ppm}$ of water, $45 \mu \mathrm{mmol}$ of base). The highly reactive $\left[{ }^{18} \mathrm{~F}\right]$ fluoride was obtained without the need of azeotropic drying procedure and effectively used in radiolabeling of the appropriate labeling precursor (up to $40 \mathrm{mg}$ ) in a solution containing BTMG (2-tert-butyl-1,1,3,3tetramethylguanidine) as an additional base.

For resin-supported fluorination [53], a glass column or PTFE tube filled with $100 \mu \mathrm{mol}$ of PS- $\mathrm{P}_{2}{ }^{\mathrm{tBu}}$ and $1200 \mathrm{mg}$ of glass beads were employed for trapping $\left[{ }^{18} \mathrm{~F}^{-} \mathrm{F}^{-}\right.$with $98 \%$ efficiency. Precursor solution (i.e., mannose triflate, $25 \mathrm{mg}$ in $3 \mathrm{~mL}$ of $\mathrm{MeCN}$ ) was then passed through the column heated to $85^{\circ} \mathrm{C}$ at a flow of $0.55 \mathrm{~mL} / \mathrm{min}$. The subsequent online basis hydrolysis on conventional tC18 Sep-Pak cartridge afforded $\left[{ }^{18} \mathrm{~F}\right] \mathrm{FDG}$ in $40 \%$ RCY in automated synthesis, with starting activity of $120 \mathrm{GBq}$. However, the success of the method depends to a great extent on the amount of resin, reaction temperature, and column packing efficiency, which, taken together, are considered a major limitation of this elegant but technically demanding production method.

The aforementioned methodologies address the synthesis of radiotracers via direct nucleophilic substitution of the appropriate leaving groups in aliphatic substrates with 
activated $\left[{ }^{18} \mathrm{~F}\right]$ fluoride as the most common route to routinely used radiotracers. The methods have been evaluated in view of possibilities for their implementation in the automated synthesizers with the aim of production of clinically useful amounts of the radiotracers. In recent years a number of highly innovative strategies to introduce the ${ }^{18} \mathrm{~F}$-label into aliphatic structures have been introduced, unfortunately, few of them are currently considered to be suitable for routine preparations of radiotracers. There have been several in-depth reviews [3,41,55-57] that offer a good overview of the current state of the art in aliphatic radiofluorinations, and deeper discussion of those more exotic approaches really lies outside the scope of the current review.

\section{3. $\left[{ }^{18}\right.$ F]Fluoride Activation for Conventional Aromatic Nucleophilic Substitution}

Traditional nucleophilic aromatic substitution $\left(S_{N} A r\right)$ reactions, including those using $\left[{ }^{18} \mathrm{~F}\right]$ fluoride as the nucleophile, require arene substrates with strong electron-withdrawing groups (EWG) such as $\mathrm{NO}_{2}, \mathrm{CN}, \mathrm{CHO}, \mathrm{COR}, \mathrm{COOR}$, and $\mathrm{CF}_{3}$ in the ortho- or para-positions of the aromatic structure combined with an appropriate leaving group $\left(\mathrm{NO}_{2}\right.$, halides, $\left.\mathrm{Me}_{3} \mathrm{~N}^{+} \mathrm{X}^{-} ; \mathrm{X}^{-}=\mathrm{TfO}^{-}, \mathrm{TsO}^{-}, \mathrm{ClO}_{4}^{-}, \mathrm{I}^{-}\right)$. Radiofluorinations are usually performed in polar, anhydrous aprotic solvents, such as DMSO, DMF, DMA, or sulfolane at moderate to high temperatures $\left(100-180{ }^{\circ} \mathrm{C}\right)$ in the presence $\mathrm{K}_{2.2 .2} / \mathrm{K}_{2} \mathrm{CO}_{3}\left(\mathrm{KHCO}_{3}\right)$ or $\mathrm{Bu}_{4} \mathrm{NHCO}_{3}$. A direct labeling strategy is an effective approach for the synthesis of ${ }^{18} \mathrm{~F}$-labeled benzaldehydes or other prosthetic groups [15] obtained through radiolabeling of substituted nitrobenzaldehydes. When it comes to the direct introduction of $\left[{ }^{18} \mathrm{~F}\right] \mathrm{F}^{-}$into biologically active molecules or drug candidates, they usually do not contain a suitably activated aryl ring for fluorination through the addition-elimination mechanism. Notable radiotracers examples accessible via direct nucleophilic substitution include (imaging target is in parenthesis): $\left[{ }^{18} \mathrm{~F}\right]$ altanserin $[58,59]$ (5-HT $\mathrm{HT}_{2 \mathrm{~A}}$ receptors); $\left[{ }^{18} \mathrm{~F}\right] \mathrm{MPPF}$ [60] (5-HT1 $\mathrm{A}$ receptors); $\left[{ }^{18} \mathrm{~F}\right]$ flumazenil [21] $\left(\mathrm{GABA}_{\mathrm{A}}\right.$ benzodiazepine receptors); [ $\left.{ }^{18} \mathrm{~F}\right] \mathrm{FPEB}$ [61] (metabotropic glutamate 5 receptors) (Figure 3 ).<smiles>O=C(c1ccc(Br)cc1)C1CCN(CCn2c(=S)[nH]c3ccccc3c2=O)CC1</smiles>

$\left[{ }^{18} \mathrm{~F}\right]$ altanserin<smiles>CCOC(=O)c1ncn2c1CN(C)C(=O)c1cc(F)ccc1-2</smiles>

$\left[{ }^{18} \mathrm{~F}\right]$ flumazenil

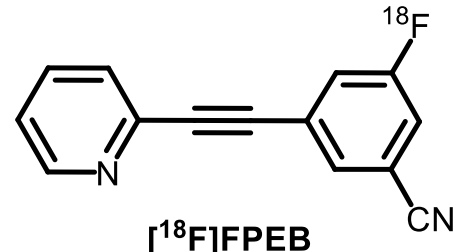

$\left[{ }^{18}\right.$ F]FPEB

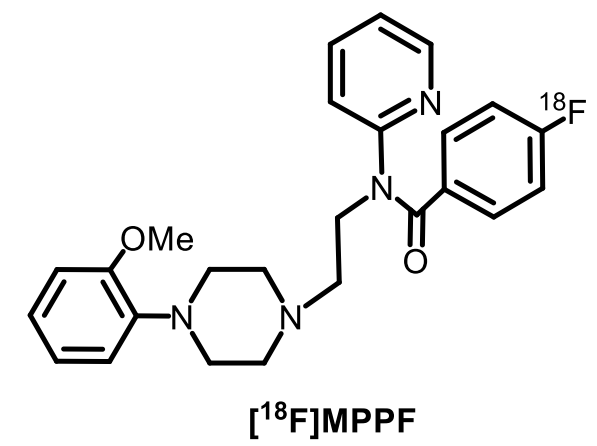

Figure 3. The structures of selected brain receptors radioligands prepared via conventional kryptofixmediated aromatic nucleophilic radiofluorination of the appropriate nitro-precursors.

These radiotracers are usually prepared through classical kryptofix-mediated substitution of a nitro leaving group in low to moderate RCYs; microwave-assisted heating has been used to improve yields [58]. In the case of heteroaromatic substitutions, particularly in the pyridine series, direct $S_{N}$ Ar fluorination on the ortho- or para-positions is feasible with no need for activation of the heteroaromatic ring. Over the years, a number of radiotracers for 
nicotine acetylcholinic receptors [62,63] as well as for imaging $\beta$-amyloid aggregates [64] and other targets have been prepared from the appropriate heteroaromatic precursors.

A recent example is the synthesis of $\left[{ }^{18}\right.$ F]PSMA-1007, a widely-used radioligand for the diagnosis and non-invasive staging of PSMA-positive prostate cancer developed by Kopka's group [65]. The radiotracer has been synthesized in high RCY (50-70\%) from its trimethylammonium salt precursor $\left(1-2 \mathrm{mg}\right.$ ) in the presence of $\mathrm{Bu}_{4} \mathrm{NHCO}_{3}$ with heating to $80-90{ }^{\circ} \mathrm{C}$ for $10 \mathrm{~min}$ in DMSO. To produce reactive $\left[{ }^{18} \mathrm{~F}\right]$ fluoride species, the radionuclide was released from the QMA cartridge $(130 \mathrm{mg})$ with $750 \mu \mathrm{L} 0.075 \mathrm{M}$ aqueous $\mathrm{TBAHCO}_{3}$ followed by an azeotropic drying procedure. In general, aryltrimethylammonium salts tend to be more reactive than neutral leaving groups. An additional benefit is that the charged precursor is easily separated from a neutral end-product using cartridge-based purification procedures. Thus, the synthesis of $\left[{ }^{18} \mathrm{~F}\right] \mathrm{PSMA}-1007$ with SPE purification can be implemented in the majority of currently available automated synthesizers [65] allowing for easy access to this important PSMA imaging agent.

The second strategy [65] to introduce ${ }^{18} \mathrm{~F}$ into PSMA-1007 relies on using 6- $\left[{ }^{18} \mathrm{~F}\right]$ fluoronicotinic acid 2,3,5,6-tetrafluorophenyl ester ( $\left.\left[{ }^{18} \mathrm{~F}\right] \mathrm{F}-\mathrm{Py}-\mathrm{TFP}\right)$, a common prosthetic reagent for the indirect peptides labeling. The unique feature of $\left[{ }^{18} \mathrm{~F}\right] \mathrm{F}-\mathrm{Py}-\mathrm{TFP}$ introduced in 2010 by Oberg and co-workers [66] is that the fluorination of the quaternary ammonium salt precursor proceeds readily at $40{ }^{\circ} \mathrm{C}$ with RCC over $65 \%$ (10 min heating in $t \mathrm{BuOH}: \mathrm{MeCN}(8: 2))$ or even at room temperature in cartridge supported [67] radiofluorination approach. The later protocol included elution of the radionuclide retained on pre-wetted Chromafix 30-PS- $\mathrm{HCO}_{3}$ with quaternary ammonium triflate precursor (5-7 mg, in $0.5 \mathrm{~mL} 1: 4 \mathrm{MeCN}: \mathrm{BuOH})$. The eluate was passed through Oasis MCX Plus cartridge, from which the product was eluted with $1 \mathrm{~mL}$ acetonitrile. The study in question presents a very effective use of so-called "minimalist" approach proposed by the Neumaier group [68], based on the direct elution of $\left[{ }^{18} \mathrm{~F}^{-}\right.$from the AECs using solutions of the precursors bearing quaternary ammonium, diaryliodonium, or triarylsulfonium functionality in alcohols, were precursors themselves act as the PTCs and do not require the addition of base. The "minimalist" method eliminates not only the need for a base or PTC but also azeotropic evaporation steps, enabling efficient fluorinations of the base-sensitive precursors.

\section{Copper-Mediated Late-Stage Radiofluorination of Non-Activated Arenes}

In the last decade or so, significant efforts have been expended on overcoming the general limitations of the conventional nucleophilic approach in direct introduction of ${ }^{18} \mathrm{~F}$ label into the non-activated aromatic ring (general structural component in a great number of potentially useful PET radiotracers), leading to approach commonly referred to as "latestage radiofluorinations." As the result of those efforts, several innovative ${ }^{18}$ F-labeling approaches for labeling of electron-rich arenes (heteroarenes) have been introduced using, for example, (mesytyl)(aryl)iodonium salts, spirocyclic hypervalent iodine (III) complexes, and organoboron and stannane precursors (for recent reviews see [69-73]).

Among the methods described, $\mathrm{Cu}$-catalyzed radiofluorination reactions using commercially-available $\mathrm{CuOTf}\left(\mathrm{CH}_{3} \mathrm{CN}\right)_{4}$ and $\mathrm{Cu}(\mathrm{OTf})_{2}(\mathrm{Py})_{4}$ complexes as sources of copper have been found to be a particularly useful route to a diverse range of complex radiopharmaceuticals that cannot be readily accessed through conventional approaches; numerous examples are presented in recent reviews [74,75]. However, attempts at the application of those methods to full-batch clinical production revealed several problems, including modest or fluctuating radiochemical yields, long synthesis times, and problematic protocols with relatively large amounts of precursors and catalysts, base sensitivities, and others. Therefore, in parallel to the development of methods for the $\mathrm{Cu}$-mediated fluorinations, substantial efforts were expended on designing novel protocols for reprocessing $\left[{ }^{18} \mathrm{~F}\right]$ fluoride that could be more easily implemented in automated modules.

Copper-mediated fluorination of (mesityl)(aryl)iodonium (MAI) salts promoted by $\mathrm{CuOTf}\left(\mathrm{CH}_{3} \mathrm{CN}\right)_{4}$ complex was recently introduced by the Sanford and Scott groups $[76,77]$ as an alternative to the use of diaryl iodonium salt precursors pioneered in 1995 by Pike's 
group [78]. Owing to their electron-deficient nature at the iodine center and simultaneous presence of an excellent leaving-group in the form of a Ph-I fragment, diaryl iodonium salts are exceptionally reactive towards nucleophilic fluorination. The most common application has been the preparation of ${ }^{18}$ F-labeled aromatic building blocks $[15,79]$ such as $4-\left[{ }^{18} \mathrm{~F}\right]$ fluoroiodobenzene, often employed in the radiolabeling via Pd-catalyzed crosscoupling reactions [80]. Notable examples of the radiopharmaceuticals accessible via fluorination of diaryl iodonium salts are 6- $\left[{ }^{18} \mathrm{~F}\right]$ fluorodopamine [81] and 6-L-[ $\left.{ }^{18} \mathrm{~F}\right] \mathrm{FDOPA}$ [82]. Despite the straightforward labeling approach, the later radiotracer, with growing clinical application in both neurology and oncology fields, was obtained from commercially available anisyl(aryl)iodonium triflate salt (Scheme 1, upper part) in relatively poor RCY of 15\% (decay-corrected) with ca. 120 min synthesis time. Using the same precursor but applying an optimized minimalist protocol [68] under cryptand/base free conditions, RCY of 6-L$\left[{ }^{18}\right.$ F]FDOPA was increased to $27-35 \%$ (decay corrected) with ca. 70 min synthesis time [83]. The major drawbacks of these methods are the requirement for high temperatures $\left(140{ }^{\circ} \mathrm{C}\right)$ as well as the use of "non-conventional" solvents such as diglyme [82] or toluene [81,83] that are not well compatible with the automated module's components [84].

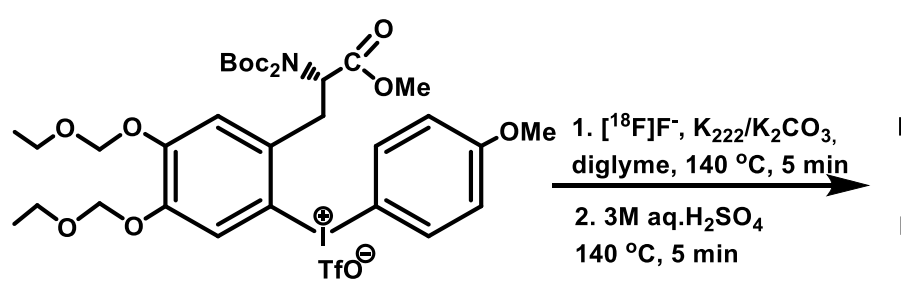<smiles>CCc1cccc(C(Br)(Br)c2c(C)cc(C)cc2C)c1</smiles><smiles>CO[Mg]</smiles>

1. Elution $\left[{ }^{18} \mathrm{~F}\right] \mathrm{F}^{-}$with precursor in $\mathrm{MeOH} / \mathrm{DMF}$ 2. $\left(\mathrm{CH}_{3} \mathrm{CN}\right)_{4} \mathrm{CuOTf} / \mathrm{DMF}$, $85^{\circ} \mathrm{C}, 20 \mathrm{~min}$

2. $10 \mathrm{~N} \mathrm{HCl}, 120^{\circ} \mathrm{C}, 10 \mathrm{~min}$

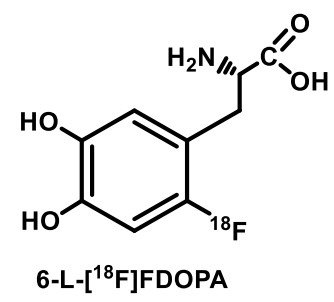

$\operatorname{RCY}($ d.c $)=14 \pm 4 \%$

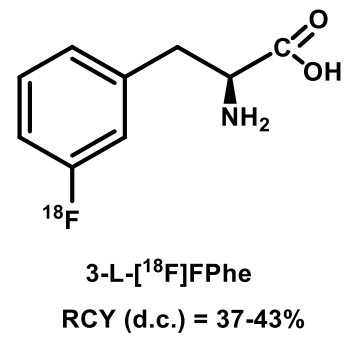

Scheme 1. Preparation of 6-L- $\left[{ }^{18} \mathrm{~F}\right]$ FDOPA [82] via ${ }^{18} \mathrm{~F}$-fluorination of anisyl(aryl)iodonium salt precursors (upper part) and synthesis of 3-[ $\left.{ }^{18} \mathrm{~F}\right]$ labeled-L-phenylalanine (lower part) using minimalist protocol [85].

In contrast, (mesityl)(aryl)iodonium (MAI) salts [77] are easily fluorinated under moderate temperatures (typically $85{ }^{\circ} \mathrm{C}, 20 \mathrm{~min}$ ) in the commonly used polar aprotic solvents such as DMF. In the original method [77], 18-crown-6/ $\mathrm{K}_{2} \mathrm{CO}_{3}$ was suggested for the activation of the $\left[{ }^{18} \mathrm{~F}\right]$ fluoride obtained in the conventional azeotropic drying procedure. Under these conditions, high RCC values (up to 80\%) were demonstrated for a series of model substrates, however, for complex molecules, such as protected 6-L- $\left[{ }^{18} \mathrm{~F}\right] \mathrm{FDOPA}$ RCC values in order of $20 \%$ were obtained using a tosylate counter ion, increasing up to $30 \%$ when a tetrafluoroborate was employed in the same role.

The high fluorination efficiency (in the order of 60-90\%, depending on the position of fluorine in the aromatic ring) was achieved [85] when implementing "minimalist" protocol [68] in the direct preparation of a series of 2,3- and 4- $\left[{ }^{18} \mathrm{~F}\right]$ labeled-L-phenylalanines, starting from respective MAI precursors (Scheme 1). $\left[{ }^{18} \mathrm{~F}\right]$ fluoride retained on the anionexchange resin was eluted with a solution of the MAI precursor in $\mathrm{MeOH} / \mathrm{DMF}$, followed by fluorination reaction in the same combination of solvents without any drying or solvent replacement steps, thus significantly simplifying automation. However, the utilization 
of this methodology for labeling electron-rich arenes is hampered by a relatively difficult preparation of the iodonium salt precursors, in particular, polyfunctionalized iodonium salts, as well as the limited shelf-life of these compounds.

Consequently, the synthesis of radiofluorinated arenes labeled in inactivated positions using arylboronic acid pinacol esters (ArylBPin) as precursors and $\mathrm{Cu}(\mathrm{OTf})_{2}(\mathrm{Py})_{4}$ as a catalyst has been recognized as a versatile route to a number of innovative ${ }^{18} \mathrm{~F}$-radiotracers and clinically significant radiopharmaceuticals [73-75]. This approach is based on copperpromoted Chan-Lam C-F cross-coupling reaction and was brought to ${ }^{18} \mathrm{~F}$-fluorine radiochemistry in 2014 by the Gouverneur's group [86] followed cold chemistry researches by the Sanford's group [87]. In the follow-up studies, Cu-mediated radiofluorination of organoborons [88] and (hetero)aryl organostannanes [89] were developed as well, however, the applications compared to ArylBPin precursors are more limited. As with most new approaches, this methodology was initially developed through small-scale experiments based on the use of small aliquots of aqueous [ $\left.{ }^{18} \mathrm{~F}\right] \mathrm{F}^{-}$and subsequent scale-up to production quantities required for generating clinical doses revealed numerous issues.

In the first application of the method [86], a conventional $\mathrm{K}_{2.2 .2} / \mathrm{K}_{2} \mathrm{CO}_{3}$ protocol with azeotropic drying was used to obtain reactive $\left[{ }^{18} \mathrm{~F}\right]$ fluoride for the reaction catalyzed by $\mathrm{Cu}(\mathrm{OTf})_{2} \mathrm{Py}_{4}$ in the presence of $\mathrm{O}_{2}$ (or atmospheric air). Due to the sensitivity of

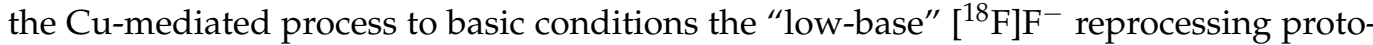
col [46] (substantially reducing both base and kryptofix amounts) or the use of less basic cryptand/base combinations [90] was suggested. Results by Gouverneur's group [86] in collaboration with other laboratories [90] demonstrated the applicability of the method to the synthesis of eight widely used radiotracers: $\left[{ }^{18} \mathrm{~F}\right] \mathrm{FMTEB},\left[{ }^{18} \mathrm{~F}\right] \mathrm{FPEB},\left[{ }^{18} \mathrm{~F}\right] \mathrm{flumazenil}$, $\left[{ }^{18} \mathrm{~F}\right] \mathrm{DAA} 1106,\left[{ }^{18} \mathrm{~F}\right] \mathrm{MFBG}, 6-\mathrm{L}-\left[{ }^{18} \mathrm{~F}\right] \mathrm{FDOPA},\left[{ }^{18} \mathrm{~F}\right] \mathrm{FMT}$, and $\left[{ }^{18} \mathrm{~F}\right] \mathrm{FDA}$ (Figure 4).

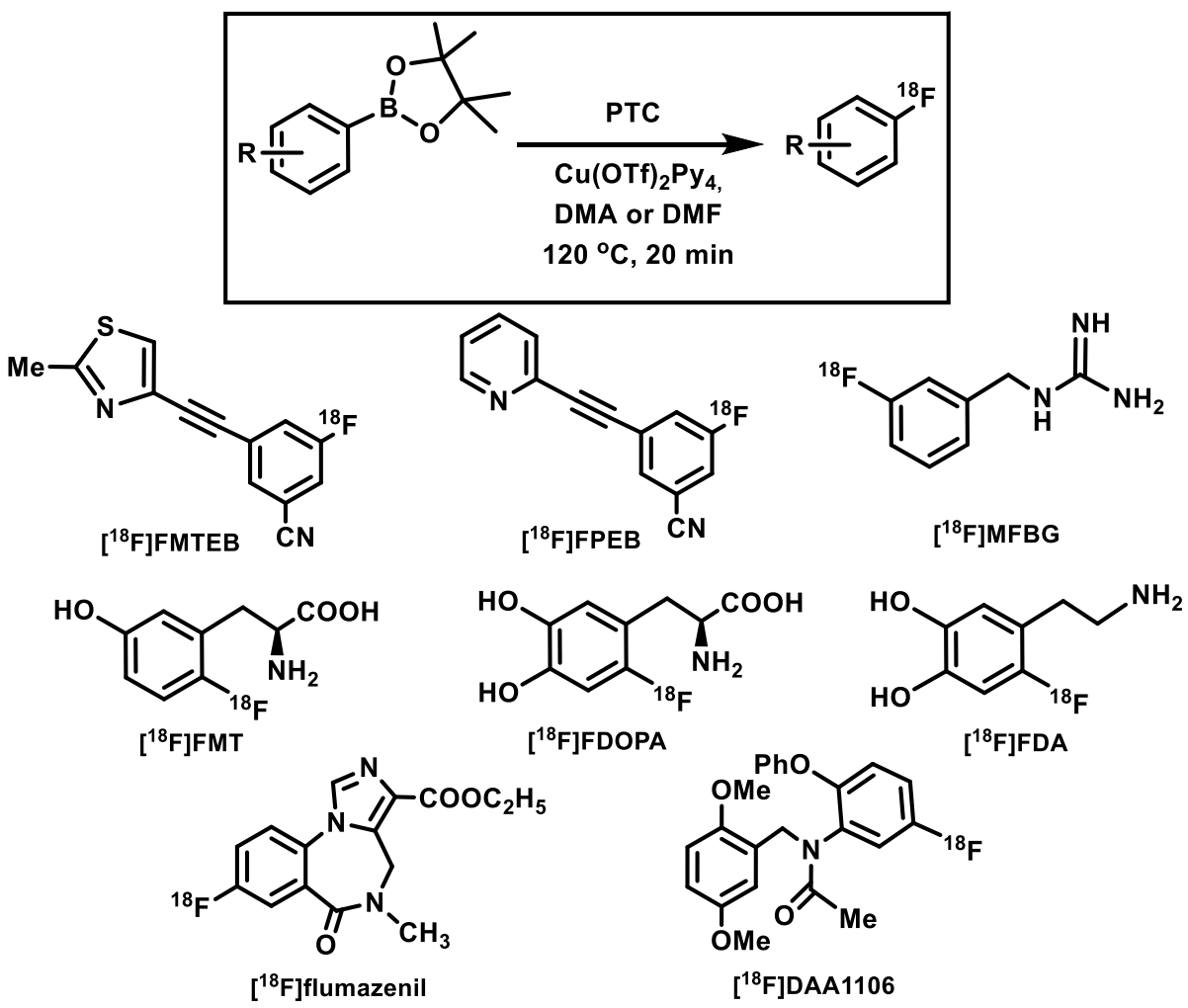

Figure 4. Synthesis of eight radiotracers via $\mathrm{Cu}$-mediated ${ }^{18} \mathrm{~F}$-fluorination of arylBPin precursors using $\mathrm{Cu}(\mathrm{OTf})_{2}(\mathrm{Py})_{4}$ as a copper source [90].

The methodology was shown to be adaptable to different automation platforms where conventional ACEs (QMA, $46 \mathrm{mg}$, or $\mathrm{PSHCO}_{3}$ ) were used for trapping and elution of the radionuclide. Depending on the particular radiotracer, different kryptofix-based eluents 
were employed with the replacement of "standard" $\mathrm{K}_{2} \mathrm{CO}_{3}$ with less basic $\mathrm{K}_{2} \mathrm{C}_{2} \mathrm{O}_{4}$ or $\mathrm{KH}_{2} \mathrm{PO}_{4}$. For example, in the preparation of 6-L- $\left[{ }^{18} \mathrm{~F}\right] \mathrm{FDOPA}$ on Synthra automated module following eluent composition was used: $\mathrm{K}_{2.2 .2}$. $(6.3 \mathrm{mg}), \mathrm{K}_{2} \mathrm{C}_{2} \mathrm{O}_{4}(1 \mathrm{mg})$ and $\mathrm{K}_{2} \mathrm{CO}_{3}$ $(0.1 \mathrm{mg})$ in $1 \mathrm{~mL}$ of $\mathrm{MeCN} / \mathrm{H}_{2} \mathrm{O}, 4: 1$. To the azeotropically dried [ $\left.{ }^{18} \mathrm{~F}\right]$ fluoride $20 \mu \mathrm{mol}$ $\mathrm{Cu}(\mathrm{OTf})_{2}(\mathrm{Py})_{4}$ and $20 \mu \mathrm{mol}$ of di-Boc precursor in anhydrous DMF $(400 \mu \mathrm{L})$ were added and the reaction mixture heated to $120^{\circ} \mathrm{C}$ for $20 \mathrm{~min}$, followed by acid hydrolysis $(57 \% \mathrm{HI}$, $150{ }^{\circ} \mathrm{C}$ for $10 \mathrm{~min}$ ). 6 -L- $\left[{ }^{18} \mathrm{~F}\right] \mathrm{FDOPA}$ was isolated in the RCY of $9 \%$ (non-decay corrected) after ca. 150 min synthesis time [90].

Further improvements of the methodology came with the employment of the weakly or non-basic organic salts in suitable aprotic or protic solvents such as $\mathrm{Et}_{4} \mathrm{NHCO}_{3}$ [91] and $\mathrm{Bu}_{4} \mathrm{NOTf}$ [92] with good solubility in organic solvents. In addition to improved radiofluorination efficiency, using solutions of these PTCs in alcohols for elution of $\left[{ }^{18} \mathrm{~F}^{-} \mathrm{F}^{-}\right.$ from conventional AECs gives additional benefits for automation through the possibility to avoid time-consuming azeotropic drying and solvent replacement steps.

In addition to the aforementioned commercially available PTCs, pyridinium sulfonate salts in organic solutions [93] have been found to be efficient for recovery of radionuclide from WAX column (1 cc, $30 \mathrm{mg}$ ) with about 80\% EE. Following such procedure $\mathrm{Cu}$-mediated radiofluorination of ArylBPin precursors using $\mathrm{Cu}(\mathrm{OTf})_{2}(\mathrm{Py})_{4}$ catalyst can be performed directly in the same solvent bypassing any solvent replacement. Using 4-dimethylaminopyridinium triflate (DMAP.OTf) in DMA $\left(110^{\circ} \mathrm{C}, 20 \mathrm{~min}\right.$, commonly used conditions for fluorination of ArylBPin $[86,90])$ the RCCs of 80-90\% were reported for seven model boronates and ArylBPin precursor for protected 4- $\left[{ }^{18}\right.$ F]fluoro-D,L-phenylalanine. In the following study [94] DMAP.OTf was used in combination with $\mathrm{Cu}(\mathrm{OTf})_{2}$. The RCCs values obtained for various model substrates in this case varied from 23 to $87 \%$; $\left[{ }^{18} \mathrm{~F}\right] \mathrm{FMZ}, \mathrm{GABA}_{\mathrm{A}}$ receptors radioligand, was obtained on a preparative scale in $47 \%$ isolated RCY with an average synthesis time of $60 \mathrm{~min}$. The general utility of $\mathrm{Cu}(\mathrm{OTf})_{2}$ in conjunction with pyridine as an alternative to $\mathrm{Cu}(\mathrm{OTf})_{2}(\mathrm{Py})_{4}$ complex was previously demonstrated by Scott's group in high-yield examples of radiofluorinations of organoboron compounds, including ArylBPin precurors, arylboronic acids [88], and arylstannanes [89] using $\mathrm{K}^{18}{ }^{18} \mathrm{FF}^{-} / \mathrm{KOTf} / \mathrm{K}_{2} \mathrm{CO}_{3}$ as the source of nucleophilic [ ${ }^{18} \mathrm{~F}$ ]fluoride. A more recent

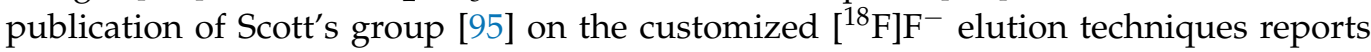
the enhancement of copper (II) triflate mediated radiofluorination of arylBPin substrates when using an aqueous solution of a weak non-ionic base such as 4-DMPA. However, using an aqueous solution necessitates the inclusion of azeotropic drying steps, making this procedure less attractive for automation. As for organic solutions of pyridinium sulfonate salts $[93,94]$, despite of their distinctive features allowing for operationally simple $\left[{ }^{18} \mathrm{~F}\right]$ fluoride processing protocol, their application in routine productions is quite limited: for clinical use commercially available materials (catalysts) is preferable.

In current practice, the procedure for alcohol-enhanced $\mathrm{Cu}$-mediated radiofluorination [91], which consists of the direct elution of the radionuclide with tetraalkylammonium salt in $n \mathrm{BuOH}$ into a solution of the precursor and $\mathrm{Cu}(\mathrm{OTf})_{2}(\mathrm{Py})_{4}$ in DMA followed by heating of resulting mixture under air has found broad application using various substrates. The presence of alcohol as co-solvent in $\mathrm{Cu}$-mediated process has a beneficial effect on the radiofluorination efficiency leading to substantial increases in the radiochemical yield of various arylBPin substrates [91,96-102]. The limitation of this approach in the original version [91] suggested by Neumaier's group is the need for a high amount of the reactants (up to $60 \mu \mathrm{mol}$ of precursor and $30 \mu \mathrm{mol}$ of $\mathrm{Cu}$-catalyst). Therefore, in the follow-up studies of the same group possibility of reduction in the amount of $\mathrm{Et}_{4} \mathrm{NHCO}_{3}$ was investigated using less viscous and more polar $\mathrm{MeOH}$ as an eluting solvent. Correspondingly, the quantities of precursor/copper catalyst could be reduced to 10-15 and 5-10 $\mu \mathrm{mol}$, respectively [96-99].

The notable feature of the "alcohol enhanced" method is the use of reverse loading/elution protocol (Figure 5) that starts with loading radionuclide onto an AEC (QMA cartridge) from the male side followed by rinsing of the resin with $\mathrm{MeOH}(2 \mathrm{~mL})$ and drying with air from the same side. Then $\left[{ }^{18} \mathrm{~F}\right] \mathrm{F}^{-}$is eluted from the female side using a 
solution of $\mathrm{Et}_{4} \mathrm{NHCO}_{3}(2 \mathrm{mg}, 10 \mu \mathrm{mol})$ in $\mathrm{MeOH}(0.5 \mathrm{~mL}) . \mathrm{MeOH}$ is evaporated using a flow of air at $80{ }^{\circ} \mathrm{C}$ within $10 \mathrm{~min}$. A solution of ArylBPin precursor $(16 \mu \mathrm{mol}, 1 \mathrm{eq})$ and $\mathrm{Cu}(\mathrm{OTf})_{2} \mathrm{Py}_{4}(20 \mu \mathrm{mol}, 1.25 \mathrm{eq})$ in $\mathrm{DMA} / n \mathrm{BuOH} 2: 1(750 \mu \mathrm{L})$ was added to $\left[{ }^{18} \mathrm{~F}\right] \mathrm{Et}{ }_{4} \mathrm{NF}$, and the resulting solution was heated at $110^{\circ} \mathrm{C}$ for $10-20 \mathrm{~min}$ under air or argon. This typical protocol has been shown to be robust, displaying broad substrate scope. However, it still required the evaporation of the solvent $(\mathrm{MeOH})$ from the eluent before fluorination.

Elution

(PTC in $\mathrm{ROH})$

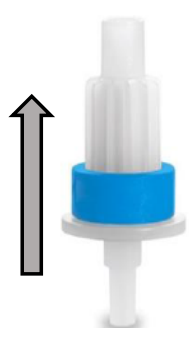

$\left[{ }^{18} \mathrm{~F}\right] \mathrm{F}^{-}$ loading

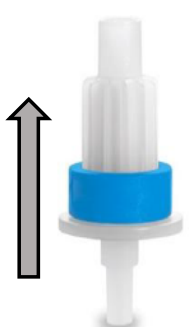

Flushing $\mathrm{N}_{2}$ flow

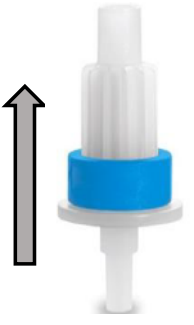

Rinsing

Figure 5. The schematic presentation of reverse loading-elution (back-flushed) protocol [92]. Step 1: $\left[{ }^{18} \mathrm{~F}\right]$ fluoride is loaded onto QMA cartridge $(130 \mathrm{mg})$ from the male side; Step 2: the cartridge is flushed from the male side by nitrogen gas for 2-3 min; Step 3: the cartridge is rinsed with $2 \mathrm{~mL}$ of $i \mathrm{PrOH}$ following drying with nitrogen from the male side; Step 4: $\left[{ }^{18} \mathrm{~F}\right]$ fluoride is eluted from the female side using a solution of $\mathrm{Bu}_{4} \mathrm{NOTf}(5 \mathrm{mg}, 12.5 \mu \mathrm{mol})$ in $i \mathrm{PrOH}(0.8 \mathrm{~mL})$.

To overcome this problem, further improvements of the methodology were introduced by our group [92] via the employment of $\mathrm{Bu}_{4}$ NOTf as non-basic PTC and low-boiling $i \mathrm{PrOH}$ for eluting $\left[{ }^{18} \mathrm{~F}\right]$ fluoride. Using reverse loading/elution protocol in conjunction with QMA cartridge of $130 \mathrm{mg}$ the $\mathrm{EE}>90 \%$ was achieved using a solution of $\mathrm{Bu}_{4} \mathrm{NOTf}$ $(5 \mathrm{mg}, 12.5 \mu \mathrm{mol})$ in $\mathrm{PrOH}(0.8 \mathrm{~mL})$. Notably, the following $\mathrm{Cu}$-mediated radiofluorination reaction can be performed directly with alcohol as co-solvent with DMA [92] or $\mathrm{MeCN}$ [92], offering significant practical benefits through elimination of not only azeotropic drying but any solvent removal steps preceding radiofluorination. Radiofluorination in DMA/ $i \mathrm{PrOH}$ was fully compatible with various model substrates and ArylBPin precursors for two aromatic amino acids. Radiofuorination in neat $i \mathrm{PrOH}$ was substrate-dependent, being particularly effective for the preparation of $6-\mathrm{L}-\left[{ }^{18} \mathrm{~F}\right] \mathrm{FDOPA}$ (reaction conditions are shown under Scheme 2). More recently ${ }^{100}$, this approach was employed in the automated synthesis of 6 -L- $\left[{ }^{18} \mathrm{~F}\right] \mathrm{FMT}$, the radiotracer representing a valuable alternative to $6-\mathrm{L}-\left[{ }^{18} \mathrm{~F}\right] \mathrm{FDOPA}$ in the diagnosis and staging of Parkinson's disease with simplified kinetic modeling. Using Bpin-substituted chiral Ni(II) complex as a labeling precursor [99], $\mathrm{Cu}$-mediated radiofluorination was performed in highly boiling $i \mathrm{PrOH} / \mathrm{MeCN}$ mixture in the presence of $\mathrm{Bu}_{4} \mathrm{NOTf}$ as the PTC affording the target radiotracer in ca. $20 \%$ activity yield (non-decay corrected) within $70 \mathrm{~min}$. The radiofluorination proceeds under nitrogen instead of air, usually applied for $\mathrm{Cu}$-mediated ${ }^{18} \mathrm{~F}$-fluorination of boronates. This could be advantageous if the module is also used for the production of other PET tracers, which require inert conditions.

The use of $\mathrm{Bu}_{4} \mathrm{NOTf}$ as a replacement for KOTf and $\mathrm{K}_{2} \mathrm{CO}_{3}$ was suggested by Scott's group [103] for the automated synthesis of 6-L-[ $\left.{ }^{18} \mathrm{~F}\right] \mathrm{FDOPA}$ (Scheme 2). An aqueous eluent consisting of $15 \mathrm{mg} / \mathrm{mL} \mathrm{Bu}_{4} \mathrm{NOTf}$ and $0.2 \mathrm{mg} / \mathrm{mL} \mathrm{Cs}_{2} \mathrm{CO}_{3}(0.5 \mathrm{~mL})$, respectively, gave good recovery of $\left[{ }^{18} \mathrm{~F}\right] \mathrm{F}^{-}$from the QMA cartridge and provided over $50 \%$ RCC in radiofluorination in DMF with addition of pyridine. However, the performance of this 
protocol necessitated a conventional azeotropic drying step resulting in a longer synthesis time (Scheme 2).

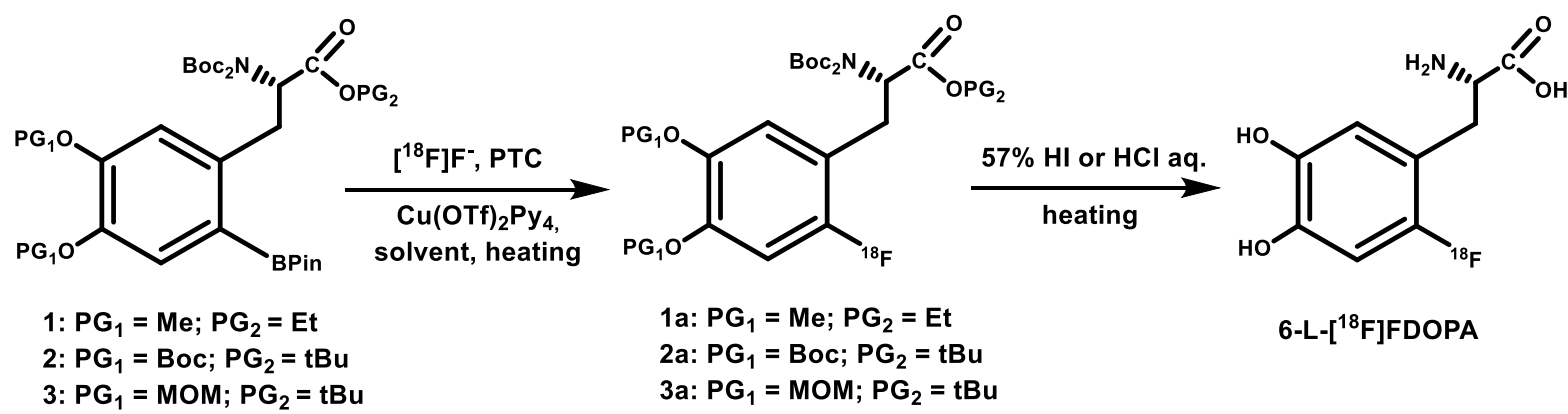

Scheme 2. Cu-mediated synthesis of 6-L- $\left[{ }^{18} \mathrm{~F}\right]$ FDOPA using various precursors (1-3) and different protocols. Precursor 1 [86]: elution- $\mathrm{K}_{2.2 .2} / \mathrm{K}_{2} \mathrm{C}_{2} \mathrm{O}_{4} / \mathrm{K}_{2} \mathrm{CO}_{3}$ in 4:1 MeCN: $\mathrm{H}_{2} \mathrm{O}$, azeotropic drying; fluorination-1 (20 $\mu \mathrm{mol})$, Cu-complex $(20 \mu \mathrm{mol}), \mathrm{DMA}, 120{ }^{\circ} \mathrm{C}, 20 \mathrm{~min}$, under air; hydrolysis: $57 \% \mathrm{HI}, 150{ }^{\circ} \mathrm{C} 15 \mathrm{~min}$; RCY 9\%, 146 min synthesis; Precursor 2 [91]: elution$\mathrm{Et}_{4} \mathrm{NHCO}_{3} / n \mathrm{BuOH}$, no azeotropic drying or solvent removal; fluorination-2 (60 $\left.\mu \mathrm{mol}\right)$, Cu-complex (53 $\mu \mathrm{mol}), \mathrm{DMA} / n \mathrm{BuOH}, 110{ }^{\circ} \mathrm{C}, 20 \mathrm{~min}$, under air; hydrolysis: $12 \mathrm{M} \mathrm{HCl}, 130{ }^{\circ} \mathrm{C}, 5 \mathrm{~min}$; $\mathrm{RCY} 40 \%$ (decay corrected), synthesis time not reported; Precursor 3 [103]: elution- $\mathrm{Bu}_{4} \mathrm{NOTf} / \mathrm{Cs}_{2} \mathrm{CO}_{3} / \mathrm{H}_{2} \mathrm{O}$, azeotropic drying; fluorination-3 $(4 \mu \mathrm{mol})$, Cu-complex $(20 \mu \mathrm{mol})$, pyridine $500 \mu \mathrm{L}$, DMF, inert atmosphere; hydrolysis: $12 \mathrm{M} \mathrm{HCl}, 0.25 \mathrm{M}$ ascorbic acid, $130{ }^{\circ} \mathrm{C}, 5 \mathrm{~min}$; RCY $6 \%$ (not decay corrected), 110 min synthesis; Precursor 3 [92]: elution- $\mathrm{Bu}_{4} \mathrm{NOTf} / \mathrm{iPrOH}$, no azeotropic drying or solvent removal; fluorination-3 $(10 \mu \mathrm{mol}), \mathrm{Cu}$-complex $(16 \mu \mathrm{mol}), \mathrm{PrOH}, 90^{\circ} \mathrm{C}, 20 \mathrm{~min}$, inert atmosphere; hydrolysis: $6 \mathrm{M} \mathrm{HCl}, \mathrm{MeOH}, 0.25 \mathrm{M}$ ascorbic acid, $110^{\circ} \mathrm{C}, 5 \mathrm{~min}$; RCY $14 \%$ (not decay corrected), 70 min synthesis.

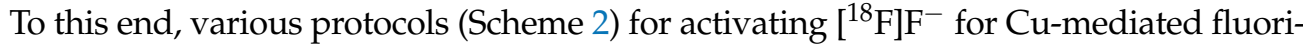
nations of arylBPin substrates have been introduced by different groups $[86,91,92,103]$ to be implemented onto automated production of $6-\mathrm{L}-\left[{ }^{18} \mathrm{~F}\right]$ FDOPA, including GMP compliant synthesis using commercially available precursor 3. Due to easy-to-cleave MOM protecting groups on the catechol moiety and tert-butyl ester group protecting the amino acid fragment in the structure of 3, hydrolysis/deprotection step can be performed using less aggressive (to compare with 57\% $\mathrm{HI}$ [86]) aqueous $\mathrm{HCl}$ solutions. Despite the reported $\mathrm{Cu}-$ mediated fluorinations of arylBPin precursors allowing the generation of multiple clinical doses using high initial radionuclide activity, they still require significant improvement in terms of activity yields.

\section{Conclusions}

$\left[{ }^{18} \mathrm{~F}\right]$ fluoride as a first step in the route to various classes of radiopharmaceuticals through $S_{N} 2$ and $S_{N}$ Ar nucleophilic substitution reactions has been explored extensively over several decades and continues to remain an important area of research when it comes to the development of new PET radiotracers. In parallel with the appearance of new radiolabeling approaches, substantial efforts are focused on the preceding reprocessing steps aimed to enhance the reactivity of the radionuclide that traditionally arrives from cyclotrons as an aqueous $\left[{ }^{18} \mathrm{~F}\right]$ fluoride ion. Usually, the $\left[{ }^{18} \mathrm{~F}\right]$ fluoride is trapped on an anionexchange resin, eluted with a mixture of $\mathrm{MeCN}$ and water containing complex of inorganic base and cryptand (typically kryptofix- $\mathrm{K}_{2.2 .2} / \mathrm{K}_{2} \mathrm{CO}_{3}$ ), and dried by repeated azeotropic distillation using MeCN. However, the time-consuming azeotropic drying is associated with radioactivity losses due to decay of the isotope, adsorption on the walls of the reactor vessel, and often is difficult to automate. Another limitation of this approach is the use of the substantial amounts of base to facilitate the elution of $\left[{ }^{18} \mathrm{~F}\right]$ fluoride from standard anion exchange cartridges commonly used. Basic reaction conditions resulting often lead to the formation of undesired radiolabeled by-products and the generation of chemical impurities 
from the decomposition of base-sensitive precursors. In order to resolve these issues considerable efforts were expended to develop novel $\left[{ }^{18} \mathrm{~F}\right]$ fluoride adsorbtion/elution protocols omitting azeotropic drying procedure and, more importantly, providing milder fluorination conditions for base-sensitive precursors. It must be stressed that the basicity of the reaction environment is one of the critical aspects that influence the yield of $\mathrm{S}_{\mathrm{N}} 2$ and $S_{N} A r$ radioflurinations, evermore so in the case of base-sensitive precursor being used. Moving away from kryptofix to tetraalkylammonium salts as PTCs often allows not only to increase the yield but can also lead to substantial simplification of overall synthetic procedure. Higher yields, lower levels of by-products, smaller amounts of precursor used, and fewer impurities formed in several cases have allowed replacing HPLC purification procedure with a cartridge-based one altogether-an immense benefit for any clinical production protocol. In this mini-review, we focused on both well-established $\left[{ }^{18} \mathrm{~F}\right]$ fluoride processing protocols already used in routine clinical productions as well as new and innovative methods and techniques in regards to possibilities of their implementation in modern automated synthesizers. By providing a comprehensive introduction and analysis of distinctive features and pitfalls of various approaches followed by a detailed description of optimized protocols for the preparation of most important radiotracers, we hope to facilitate the implementation of the new techniques described into future clinical-production scale ${ }^{18}$ F-fluorination.

Author Contributions: R.N.K. conceived and designed the review concept; V.V.O. reviewed the papers on Cu-mediated fluorination; R.N.K. and V.V.O. wrote the draft manuscript; R.N.K. finalized the paper. All authors have read and agreed to the published version of the manuscript.

Funding: This work was supported by the state assignment of the Ministry of Education and Science of the Russian Federation, theme number 0133-2019-0004. The contribution of V.V.O. was funded by the Russian Foundation of Basic Researches 20-53-12030 $\backslash 21$.

Institutional Review Board Statement: Not applicable.

Informed Consent Statement: Not applicable.

Data Availability Statement: Not applicable.

Conflicts of Interest: The authors declare no conflict of interest.

\section{References}

1. Eberl, S.; Eriksson, T.; Svedberg, O.; Norling, J.; Henderson, D.; Lam, P.; Fulham, M.J. High Beam Current Operation of a PETtraceTM Cyclotron for ${ }^{18} \mathrm{~F}^{-}$Production. Appl. Radiat. Isot. 2012, 70, 922-930. [CrossRef]

2. Cai, L.; Lu, S.-Y.; Pike, V.W. Chemistry with [ ${ }^{18}$ F]Fluoride Ion. Eur. J. Org. Chem. 2008, 17, 2853-2873. [CrossRef]

3. Coenen, H.H.; Ermert, J. ${ }^{18}$ F-labelling innovations and their potential for clinical application. Clin. Trans. Imaging 2018, 6, 16. [CrossRef]

4. Deng, X.; Rong, J.; Wang, L.; Vasdev, N.; Zhang, L.; Josephson, L.; Liang, S.H. Chemistry for Positron Emission Tomography: Recent Advances in ${ }^{11} \mathrm{C}-,{ }^{18} \mathrm{~F}-,{ }^{13} \mathrm{~N}-$, and ${ }^{15} \mathrm{O}-$ Labeling Reactions. Angew. Chem. Int. Ed. 2019, 58, 2580-2605. [CrossRef]

5. Jacobson, O.; Kiesewetter, D.O.; Chen, X. Fluorine-18 Radiochemistry, Labeling Strategies and Synthetic Routes. Bioconjugate Chem. 2014, 26, 1-18. [CrossRef] [PubMed]

6. Schlyer, D.J.; Bastos, M.A.V.; Alexoff, D.; Wolf, A.P. Separation of $\left[{ }^{18} \mathrm{~F}\right]$ fluoride from $\left[{ }^{18} \mathrm{O}\right]$ water using anion exchange resin. Appl. Radiat. Isot. 1990, 41, 531-533. [CrossRef]

7. Sachinidis, J.I.; Poniger, S.; Tochon-Danguy, H.J. Automation for Optimised Production of Fluorine-18-Labelled Radiopharmaceuticals. Curr. Radiopharm. 2010, 3, 248-253. [CrossRef]

8. Hjelstuen, O.K.; Svadberg, A.; Olberg, D.E.; Rosser, M. Standardization of fluorine-18 manufacturing processes: New scientific challenges for PET. Eur. J. Pharm. Biopharm. 2011, 78, 307-313. [CrossRef] [PubMed]

9. Krasikova, R. PET Radiochemistry automation: State of the art and future trends in ${ }^{18}$ F-nucleophilic fluorination. Curr. Org. Chem. 2013, 17, 2097-2107. [CrossRef]

10. Coenen, H.H.; Schuller, M.; Stocklin, G.; Klatte, B.; Knochel, A. Preparation of N.C.A. $\left[17-{ }^{18}\right.$ F]-fluoroheptadecanoic acid in high yields via aminopolyether supported, nucleophilic fluorination. J. Labelled. Compds. Radiopharm. 1986, 23, 455-466. [CrossRef]

11. Hamacher, K.; Coenen, H.; Stocklin, G. Efficient stereospecifc synthesis of no-carrier-added 2-[F-18]-fuoro-2-deoxy-d-glucose using aminopolyether supported nucleophilic-substitution. J. Nucl. Med. 1986, 27, 235-238. [PubMed] 
12. Coenen, H.H.; Elsinga, P.H.; Iwata, R.; Kilbourn, M.R.; Pillai, M.R.; Rajan, M.G.; Wagner, H.N.; Zagnun, J.J. Fluorine-18 radiopharmaceuticals beyond $\left.{ }^{18} \mathrm{~F}\right]$ FDG for use in oncology and neurosciences. Nucl. Med. Biol. 2010, 37, 727-740. [CrossRef] [PubMed]

13. Brodack, J.W.; Kilbourn, M.R.; Welch, M.J.; Katzenellenbogen, J.A. NCA 16 alpha-[ $\left[{ }^{18}\right.$ F]fluoroestradiol-17 beta: The effect of reaction vessel on fluorine-18 resolubilization, product yield, and effective specific activity. Int. J. Rad. Appl. Instrum. A 1986, 37, 217-221. [CrossRef]

14. Zhang, M.-R.; Suzuki, K. $\left[{ }^{18}\right.$ F]Fluoroalkyl agents: Synthesis, reactivity and application for development of PET ligands in molecular imaging. Curr. Top. Med. Chem. 2007, 7, 1817-1828. [CrossRef]

15. Van der Born, D.; Pees, A.; Poot, A.J.; Orru, R.V.A.; Windhorst, A.D.; Vugts, D.G. Fluorine-18 labelled building blocks for PET tracer synthesis. Chem. Soc. Rev. 2017, 46, 4709-4773. [CrossRef] [PubMed]

16. Gomzina, N.A.; Zaitsev, V.V.; Krasikova, R.N. Optimization of nucleophilic fluorination step in the synthesis of various compounds labelled with fluorine-18 for their use as PET radiotracers. J. Label. Compds. Radiopharm. 2001, 44 (Suppl. S1), S895-S897. [CrossRef]

17. Gomzina, N.A.; Vassiliev, D.A.; Krasikova, R.N. Optimization of robotic preparation of 2-[ ${ }^{18}$ F $]$ fluoro-2-deoxy-D-glucose based on alkali hydrolysis. Radiochemistry 2002, 44, 366-372. [CrossRef]

18. Fedorova, O.S.; Vaitekhovich, F.P.; Krasikova, R.N. Automated synthesis of $\left[{ }^{18} \mathrm{~F}\right]$ fluoromethylcholine for positron emission tomography imaging. Pharm. Chem. J. 2018, 52, 730-734. [CrossRef]

19. Fedorova, O.; Nikolaeva, V.; Krasikova, R. Automated SPE-based synthesis of $16 \alpha-\left[{ }^{18} \mathrm{~F}\right]$ fluoroestradiol without HPLC purification step. Appl. Radiat. Isot. 2018, 141, 57-63. [CrossRef]

20. Li, G.Y.; Vaulina, D.D.; Li, J.J.; Fedorova, O.S.; Wang, H.E.; Liu, R.S.; Krasikova, R.N.; Chen, C.L. Synthesis and biological evaluation of 2-(3,4-dimethoxyphenyl)-6-(2-[ $\left.{ }^{18} \mathrm{~F}\right]$ fluoroethoxy)benzothiazole $\left(\left[{ }^{18} \mathrm{~F}\right] \mathrm{FEDBT}\right)$ for PET imaging of breast cancer. Bioorg. Med. Chem. Lett. 2017, 27, 3460-3463. [CrossRef]

21. Ryzhikov, N.N.; Seneca, N.; Krasikova, R.N.; Gomzina, N.A.; Shchukin, E.; Fedorova, O.S.; Vassiliev, D.A.; Gulyás, B.; Hall, H.; Savic, I.; et al. Preparation of high specific radioactivity $\left[{ }^{18} \mathrm{~F}\right]$ flumazenil and its evaluation in cynomolgus monkey by positron emission tomography. Nucl. Med. Biol. 2005, 32, 109-116. [CrossRef]

22. Stepanov, V.; Krasikova, R.; Raus, L.; Loog, O.; Hiltunen, J.; Halldin, C. An Efficient One-Step Radiosynthesis of [ ${ }^{18}$ F]FEPE2I, a PET Radioligand for Imaging of Dopamine Transporters. J. Label. Compd. Radiopharm. 2012, 55, 206-210. [CrossRef]

23. Arakawa, R.; Takano, A.; Stenkrona, P.; Stepanov, V.; Nag, S.; Jahan, M.; Grybäck, P.; Bolin, M.; Chen, L.; Zhang, L.; et al. PET imaging of beta-secretase 1 in the human brain: Radiation dosimetry, quantification, and test-retest examination of [ $\left.{ }^{18} \mathrm{~F}\right] \mathrm{PF}-$ 06684511. Eur. J. Nucl. Med. Mol. Imaging 2020, 47, 2429-2439. [CrossRef] [PubMed]

24. Finnema, S.J.; Stepanov, V.; Nakao, R.; Sromek, A.W.; Zhang, T.; Neumeyer, J.L.; George, S.R.; Seeman, P.; Stabin, M.G.; Jonsson, C.; et al. (18)F-MCL-524, an (18)F-Labeled Dopamine D2 and D3 Receptor Agonist Sensitive to Dopamine: A Preliminary PET Study. J. Nucl. Med. 2014, 55, 1164-1170. [CrossRef] [PubMed]

25. Bogni, A.; Laera, L.; Cucchi, C.; Iwata, R.; Seregni, E.; Pascali, C. An improved automated one-pot synthesis of $O^{\prime}-(2-$ $\left[{ }^{18} \mathrm{~F}\right]$ fluoroethyl)-L-tyrosine $\left(\left[{ }^{18} \mathrm{~F}\right] \mathrm{FET}\right)$ based on a purification by cartridges. Nucl. Med. Biol. 2019, 72-73, 11-19. [CrossRef] [PubMed]

26. Cucchi, C.; Bogni, A.; Casanova, C.; Seregini, E.; Pascali, C. An improved one-pot preparation of [ ${ }^{18}$ F]FMISO based on solid phase extraction purification: Pitfalls on the analytical method reported in the Ph.Eur.'s monograph. J. Label. Compd. Radiopharm. 2021, 1-7. [CrossRef]

27. Wessmann, S.H.; Henriksen, G.; Wester, H.J. Cryptate mediated nucleophilic 18F-fluorination without azeotropic drying Nuklearmedizin 2012, 51, 1-8. [CrossRef]

28. Wurzer, A.; Di Carlo, D.; Schmidt, A.; Beck, R.; Eiber, M.; Schwaiger, M.; Wester, H.-J. Radiohybrid Ligands: A Novel Tracer Concept Exemplified by ${ }^{18} \mathrm{~F}$ - or ${ }^{68} \mathrm{Ga}$-Labeled rhPSMA Inhibitors. J. Nucl. Med. 2020, 61, 735-742. [CrossRef]

29. Kostikov, A.P.; Chin, J.; Orchowski, K.; Niedermoser, S.; Kovacevic, M.M.; Aliaga, A.; Jurkschat, K.; Wängler, B.; Wängler, C.; Wester, H.J.; et al. Oxalic acid supported Si- ${ }^{18}$ F-radiofluorination: One-step radiosynthesis of N-succinimidyl 3-(di-tertbutyl $\left[{ }^{18} \mathrm{~F}\right]$ fluorosilyl)benzoate $\left(\left[{ }^{18} \mathrm{~F}\right] \mathrm{SiFB}\right)$ for protein labeling. Bioconjug Chem. 2012, 3, 106-114. [CrossRef]

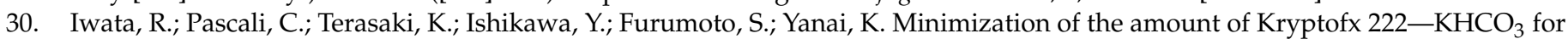
applications to microscale ${ }^{18} \mathrm{~F}$-radiolabeling. Appl. Radiat. Isot. 2017, 125, 113-118. [CrossRef]

31. Song, R.; Tago, T.; Tatsuta, M.; Shiraishi, N.; Iwai, K.; Hirano, K.; Toyohara, D.; Tanaka, H. N-Alkyl 3-aminobut-2-enenitrile as a Non-radioactive Side Product in Nucleophilic ${ }^{18}$ F-Fluorination. ChemistrySelect 2021, 6, 2826-2831. [CrossRef]

32. Kwon, Y.D.; Son, J.; Yun, M.J.; Chun, J.H. Azeotropic drying-free aliphatic radiofuorination to produce PET radiotracers in a mixed organic solvent system. Tetrahedron Lett. 2018, 59, 2848-2852. [CrossRef]

33. Aerts, J.; Voccia, S.; Lemaire, C.; Giacomelli, F.; Goblet, D.; Thonon, D.; Plenevaux, A.; Warnock, G.; Luxen, A. Fast production of highly concentrated reactive $\left[{ }^{18} \mathrm{~F}\right]$ fluoride for aliphatic and aromatic nucleophilic radiolabelling. Tetrahedron Lett. 2010, 51, 64-66. [CrossRef]

34. Culbert, P.A.; Adam, M.J.; Hurtado, E.T.; Huser, J.M.A.; Jivan, S.; Lu, J.; Ruth, T.J.; Zeisler, S.K. Automated synthesis of [ ${ }^{18}$ F]FDG using tetrabutylammonium bicarbonate. Appl. Radiat. Isot. 1995, 46, 887-891. [CrossRef]

35. Hamacher, K.; Coenen, H.H. Efficient routine production of the ${ }^{18}$ F-labelled amino acid O'-(2-[ ${ }^{18}$ F $]$ fluoroethyl)-L-tyrosine. Appl. Radiat. Isot. 2002, 57, 853-856. [CrossRef] 
36. Krasikova, R.N.; Kuznetsova, O.F.; Fedorova, O.S.; Maleev, V.I.; Savel'eva, T.F.; Belokon, Y.N. No carrier added synthesis of O-(2'-[18F]fluoroethyl)-L-tyrosine via a novel type of chiral enantiomerically pure precursor, NiII complex of a (S)-tyrosine Schiff base. Bioorg. Med. Chem. 2008, 16, 4994-5003. [CrossRef]

37. Jiang, X.; Li, Y.; Wang, X.; Shen, T.; Li, X.; Yao, Y.; Zhang, G.; Kou, Y.; Shen, J.; Luo, Z.; et al. Quick Automatic Synthesis of Solvent-Free $16 \alpha-\left[{ }^{18}\right.$ F]Fluoroestradiol: Comparison of Kryptofix 222 and Tetrabutylammonium Bicarbonate. Front. Oncol. 2020, 10, 577979. [CrossRef]

38. Krasikova, R.N.; Kuznetsova, O.F.; Fedorova, O.S.; Belokon, Y.N.; Maleev, V.I.; Mu, L.; Ametamey, S.; Schubiger, P.A.; Friebe, M.; Berndt, M.; et al. 4- $\left[{ }^{18}\right.$ F]fluoro glutamic acid (BAY 85-8050)—A new amino acid radiotracer for PET imaging of tumors: Synthesis and in vitro characterization. J. Med. Chem. 2011, 54, 406-410. [CrossRef]

39. Brichard, L.; Aigbirhio, F.I. An Efficient Method for Enhancing the Reactivity and Flexibility of $\left[{ }^{18}\right.$ F]Fluoride Towards Nucleophilic Substitution Using Tetraethylammonium Bicarbonate. Eur. J. Org. Chem. 2014, 28, 6145-6149. [CrossRef]

40. Cybulska, K.A.; Bloemers, V.; Perk, L.R.; Laverman, P. Optimised GMP-compliant production of $\left[{ }^{18}\right.$ F]DPA-714 on the Trasis AllinOne module. EJNMMI Radiopharm. Chem. 2021, 6, 20. [CrossRef]

41. Bratteby, K.; Shalgunov, V.; Herth, M. Aliphatic ${ }^{18} \mathrm{~F}$-Radiofluorination: Recent Advances in the Labeling of Base-Sensitive Substrates. ChemMedChem. 2021, 16, 2612-2622. [CrossRef]

42. Orlovskaya, V.; Antuganov, D.; Fedorova, O.; Timofeev, V.; Krasikova, R. Tetrabutyl ammonium tosylate as inert phase-transfer catalyst: The key to high efficiency $\mathrm{S}_{\mathrm{N}} 2$ radiofluorinations. Appl. Radiat. Isot. 2020, 163, 109195. [CrossRef]

43. Bratteby, K.; Shalgunov, V.; Battisti, U.M.; Petersen, I.N.; Broek, S.L.; Ohlsson, T.; Gillings, N.; Erlandsson, M.; Herth, M. Insights into Elution of Anion Exchange Cartridges: Opening the Path towards Aliphatic ${ }^{18} \mathrm{~F}$-Radiolabeling of Base-Sensitive Tracers. ACS Pharmacol. Transl. Sci. 2021, 4, 1556-1566. [CrossRef]

44. Inkster, J.A.H.; Akurathi, V.; Sromek, A.W.; Chen, Y.; Neumeyer, J.L.; Packard, A.B. A non-anhydrous, minimally basic protocol for the simplification of nucleophilic ${ }^{18}$ F-fluorination chemistry. Sci. Rep. 2020, 10, 6818. [CrossRef] [PubMed]

45. Seo, J.W.; Lee, B.S.; Lee, S.J.; Oh, S.J.; Chi, D.Y. Fast and easy drying method for the preparation of activated $\left.{ }^{18} \mathrm{~F}\right]$ fluoride using polymer cartridge. Bull. Korean Chem. Soc. 2011, 32, 71-76. [CrossRef]

46. Zlatopolskiy, B.D.; Zischler, J.; Krapf, P.; Zarrad, F.; Urusova, E.A.; Kordys, E.; Endepols, H.; Neumaier, B. Copper-mediated aromatic radiofluorination revisited: Efficient production of PET tracers on a preparative scale. Chem. Eur. J. 2015, 21, 5972-5979. [CrossRef] [PubMed]

47. Orlovskaya, V.; Fedorova, O.; Nadporojskii, M.; Krasikova, R. A fully automated azeotropic drying free synthesis of O-(2$\left[{ }^{18} \mathrm{~F}\right]$ fluoroethyl)-L-tyrosine $\left(\left[{ }^{18} \mathrm{~F}\right] \mathrm{FET}\right)$ using tetrabutylammonium tosylate. Appl. Radiat. Isot. 2019, 152, 135-139. [CrossRef]

48. Fedorova, O.S.; Orlovskaya, V.V.; Nadporojskii, M.; Krasikova, R.N. Automated synthesis of the $16 \alpha-\left[{ }^{18} \mathrm{~F}\right]$ fluoroestradiol ([ $\left.\left.{ }^{18} \mathrm{~F}\right] \mathrm{FES}\right)$ : Minimization of precursor amount and resulting benefits. Radiochim. Acta 2020, 108, 979-988. [CrossRef]

49. Bratteby, K.; Denholt, C.L.; Lehel, S.; Petersen, I.N.; Madsen, J.; Erlandsson, M.; Ohlsson, T.; Herth, M.; Gillings, N. Fully Automated GMP-Compliant Synthesis of [ ${ }^{18}$ F]FE-PE2I. Pharmaceuticals 2021, 14, 601. [CrossRef]

50. Inkster, J.A.H.; Sromek, A.W.; Akurathi, V.; Neumeyer, J.L.; Packard, A.B. The Non-Anhydrous, Minimally Basic Synthesis of the Dopamine D2 Agonist [ ${ }^{18}$ F]MCL-524. Chemistry 2021, 3, 1047-1056. [CrossRef]

51. Toorongian, S.A.; Mulholland, K.; Jewett, D.M.; Bachelor, M.A.; Kilbourn, M.R. Routine production of 2-deoxy-2-[ ${ }^{18}$ F]fluoroD-glucose by direct nucleophilic exchange on a quaternary 4-aminopyridinium resin. Int. J. Radiat. Appl. Instrum. B 1990, 17, 273-279. [CrossRef]

52. Kuge, Y.; Tsukamoto, E.; Katoh, C.; Seki, K.; Ohkura, K.; Ohmiya, Y.; Nishijima, K.; Tanaka, A.; Sasaki, M.; Tamaki, N. Synthesis of ${ }^{18}$ F-FDG with FDG MicroLab system: Basic studies for clinical application. Jpn. J. Nucl. Med. 1999, 36, 873-878. [PubMed]

53. Mathiessen, B.; Zhuravlev, F. Automated Solid-Phase Radiofluorination Using Polymer-Supported Phosphazenes. Molecules 2013, 18, 10531-10547. [CrossRef] [PubMed]

54. Lemaire, C.F.; Aerts, J.; Voccia, S.; Libert, L.C.; Mercier, F.; Goblet, D.; Plenevaux, A.R.; Luxen, A.J. Fast Production of Highly Reactive No-Carrier-Added $\left[{ }^{18}\right.$ F]Fluoride for the Labeling of Radiopharmaceuticals. Angew. Chem. Int. Ed. 2010, 49, 3161-3164. [CrossRef] [PubMed]

55. Rong, J.; Liang, S.H. Aliphatic $\left[{ }^{18}\right.$ F]Fluorination Chemistry for Positron Emission Tomography. In Fluorination, Synthetic Organofluorine Chemistry 1; Hu, J., Umemoto, T., Eds.; Springer Nature Singapore Pte Ltd.: Singapore, 2018. [CrossRef]

56. Liang, S.H.; Vasdev, N. Aliphatic ${ }^{18} \mathrm{~F}$ Bond Formation via Transition Metal Based $\left[{ }^{18} \mathrm{~F}\right]$ Fluorination. Angew. Chem. Int. Ed. Engl. 2014, 53, 11416-11418. [CrossRef]

57. Thompson, S.; Lee, S.J.; Jackson, I.M.; Ichiishi, N.; Brooks, A.F.; Sanford, M.S.; Scott, P.J.H. Synthesis of $\left[{ }^{18}\right.$ F]- $\gamma-$ Fluoro- $\alpha, \beta-$ unsaturated Esters and Ketones via Vinylogous ${ }^{18}$ F-Fluorination of $\alpha$-Diazoacetates with $\left[{ }^{18} \mathrm{~F}\right] \mathrm{AgF}$. Synthesis 2019, 51, $4401-4407$. [CrossRef]

58. Lemaire, C.; Cantineau, R.; Guillaume, M.; Plenevaux, A.; Christiaens, L. Fluorine-18-altanserin: A radioligand for the study of serotonin receptors with PET: Radiolabeling and in vivo biologic behavior in rats. J. Nucl. Med. 1991, 32, 2266-2272. [PubMed]

59. Hasler, F.; Kuznetsova, O.F.; Krasikova, R.N.; Cservenyak, T.; Quednow, B.B.; Vollenweider, F.X.; Ametamey, S.M.; Westera, G. GMP-compliant radiosynthesis of $\left[{ }^{18} \mathrm{~F}\right]$ altanserin and human plasma metabolite studies. Appl. Radiat. Isot. 2009, 67, 598-601. [CrossRef] 
60. Le, B.D.; Lemaire, C.; Ginovart, N.; Plenevaux, A.; Aerts, J.; Brihaye, C.; Hassoun, W.; Leviel, V.; Mekhsian, P.; Weissmann, D.; et al. High-yield radiosynthesis and preliminary in vivo evaluation of $p-\left[{ }^{18} \mathrm{~F}\right] \mathrm{MPPF}$, a fuoro analog of WAY-100635. Nucl. Med. Biol. 1998, 25, 343-350. [CrossRef]

61. Wong, D.F.; Waterhouse, R.; Kuwabara, H.; Kim, J.; Brašić, J.R.; Chamroonrat, W.; Stabins, M.; Holt, D.P.; Dannals, R.F.; Hamill, T.G.; et al. 18F-FPEB, a PET Radiopharmaceutical for quantifying metabotropic glutamate 5 receptors: A first-in-human study of radiochemical safety, biokinetics, and radiation dosimetry. J. Nucl. Med. 2013, 54, 388-396. [CrossRef]

62. Dollé, F. Fluorine-18-labelled fuoropyridines: Advances in radiopharmaceutical design. Curr. Pharm. Des. 2005, 11, $3221-3235$. [CrossRef] [PubMed]

63. Horti, A.; Koren, A.O.; Ravert, H.T.; Musachio, J.L.; Mathews, W.B.; London, E.D.; Dannals, R.F. Synthesis of a radiotracer for studying nicotinic acetylcholine receptors: $2-\left[{ }^{18} \mathrm{~F}\right]$ Fluoro-3-(2(S)- azetidinylmethoxy)pyridine $\left(2-\left[{ }^{18} \mathrm{~F}\right] \mathrm{F}-\mathrm{A}-85380\right)$. J. Label. Compds. Radiopharm. 1998, 41, 309-318. [CrossRef]

64. Cselényi, Z.; Jönhagen, M.E.; Forsberg, A.; Halldin, C.; Julin, P.; Schou, M.; Johnström, P.; Varnäs, K.; Svensson, S.; Farde, L. Clinical validation of ${ }^{18}$ F-AZD4694, an amyloid- $\beta$-specific PET radioligand. J. Nucl. Med. 2012, 53, 415-424. [CrossRef] [PubMed]

65. Cardinale, J.; Martin, R.; Remde, Y.; Schäfer, M.; Hienzsch, A.; Hübner, S.; Zerges, A.M.; Marx, H.; Hesse, R.; Weber, K.; et al. Procedures for the GMP-Compliant Production and Quality Control of [ ${ }^{18}$ F]PSMA-1007: A Next Generation Radiofluorinated Tracer for the Detection of Prostate Cancer. Pharmaceuticals 2017, 10, 77. [CrossRef] [PubMed]

66. Olberg, D.E.; Arukwe, J.M.; Hjelstuen, O.K.; Solbakken, M.; Kindberg, G.M.; Cuthbertson, A. One Step Radiosynthesis of 6- $\left[{ }^{18} \mathrm{~F}\right]$ Fluoronicotinic Acid 2,3,5,6-Tetrafluorophenyl Ester $\left(\left[{ }^{18} \mathrm{~F}\right] \mathrm{F}-\mathrm{Py}-\mathrm{TFP}\right)$ : A New Prosthetic Group for Efficient Labeling of Biomolecules with Fluorine-18. J. Med. Chem. 2010, 53, 1732-1740. [CrossRef]

67. Basuli, F.; Zhang, X.; Jagoda, E.M.; Choyke, P.L.; Swenson, R.E. Facile room temperature synthesis of fluorine-18 labeled fluoronicotinic acid-2,3,5,6-tetrafluorophenyl ester without azeotropic drying of fluorine-18. Nucl. Med. Biol. 2016, 43, 770-772. [CrossRef]

68. Richarz, R.; Krapf, P.; Zarrad, F.; Urusova, E.A.; Neumaier, B.; Zlatopolskiy, B.D. Neither azeotropic drying, nor base nor other additives: A minimalist approach to ${ }^{18}$ F-labeling. Org. Biomol. Chem. 2014, 12, 8094-8099. [CrossRef]

69. Lee, E.; Kamlet, A.S.; Powers, D.C.; Neumann, C.N.; Boursalian, G.B.; Furuya, T.; Choi, D.C.; Hooker, J.M.; Ritter, T. A FluorideDerived Electrophilic Late-Stage Fluorination Reagent for PET Imaging. Science 2011, 334, 639-642. [CrossRef]

70. Brooks, A.F.; Topczewski, J.J.; Ichiishi, N.; Sanford, M.S.; Scott, P. Late-Stage $\left[{ }^{18}\right.$ F]fluorination: New Solutions to Old Problems. Chem. Sci. 2014, 5, 4545-4553. [CrossRef]

71. Taylor, N.J.; Emer, E.; Preshlock, S.; Schedler, M.; Tredwell, M.; Verhoog, S.; Mercier, J.; Genicot, C.; Gouverneur, V. Derisking the Cu-Mediated ${ }^{18}$ F-Fluorination of Heterocyclic Positron Emission Tomography Radioligands. J. Am. Chem. Soc. 2017, 139, 8267-8276. [CrossRef]

72. Cole, E.L.; Stewart, M.N.; Littich, R.; Hoareau, R.; Scott, P. Radiosyntheses Using Fluorine-18: The Art and Science of Late Stage Fluorination. Curr. Top. Med. Chem. 2014, 14, 875-900. [CrossRef]

73. Preshlock, S.; Tredwell, M.; Gouverneur, V. ${ }^{18}$ F-Labeling of Arenes and Heteroarenes for Applications in Positron Emission Tomography. Chem. Rev. 2016, 116, 719-766. [CrossRef]

74. Zarganes-Tzitzikas, T.; Clemente, G.S.; Elsinga, P.H.; Dömling, A. MCR Scaffolds Get Hotter With ${ }^{18}$ F-Labeling. Molecules 2019, 24, 1327. [CrossRef]

75. Wright, J.S.; Kaur, T.; Preshlock, S.; Tanzey, S.S.; Winton, W.P.; Sharninghausen, L.S.; Wiesner, N.; Brooks, A.F.; Sanford, M.S.; Scott, P. Copper-Mediated Late-Stage Radiofluorination: Five Years of Impact on Preclinical and Clinical PET Imaging. Clin. Transl. Imaging 2020, 8, 167-206. [CrossRef]

76. Ichiishi, N.; Canty, A.J.; Yates, B.F.; Sanford, M.S. Cu-Catalyzed Fluorination of Diaryliodonium Salts With KF. Org. Lett. 2013, 15, 5134-5137. [CrossRef] [PubMed]

77. Ichiishi, N.; Brooks, A.F.; Topczewski, J.J.; Rodnick, M.E.; Sanford, M.S.; Scott, P. Copper-Catalyzed $\left[{ }^{18}\right.$ F]Fluorination of (Mesityl)(aryl)iodonium Salts. Org. Lett. 2014, 16, 3224-3227. [CrossRef]

78. Pike, V.W.; Aigbirhio, F.I. Reactions of Cyclotron-Produced $\left[{ }^{18} \mathrm{~F}\right]$ fluoride With Diaryliodonium salts-A novel Single-Step Route to No-Carrier-Added [18F]fluoroarenes. J. Chem. Soc. Chem. Commun. 1995, 21, 2215. [CrossRef]

79. Pike, V.W. Hypervalent Aryliodine Compounds as Precursors for Radiofluorination. J. Label. Compd. Radiopharm. 2018, 61, 196-227. [CrossRef] [PubMed]

80. Way, J.D.; Wuest, F. Automated radiosynthesis of no-carrier-added $4-\left[{ }^{18} \mathrm{~F}\right]$ fluoroiodobenzene: A versatile building block in ${ }^{18} \mathrm{~F}$ radiochemistry. J. Label. Compds. Radiopharm. 2014, 57, 104-109. [CrossRef]

81. Vāvere, A.L.; Neumann, K.D.; Butch, E.R.; Hu, B.; DiMagno, S.G.; Snyder, S.E. Improved, one-pot synthesis of 6-[18 F]fluorodopamine and quality control testing for use in patients with neuroblastoma. J. Label. Comp. Radiopharm. 2018, 61, 1069-1080. [CrossRef]

82. Kuik, W.-J.; Kema, I.P.; Brouwers, A.H.; Zijlma, R.; Neumann, K.D.; Dierckx, R.A.J.O.; DiMagno, S.G.; Elsinga, P.H. In Vivo Biodistribution of No-Carrier-Added 6-18F-Fluoro-3,4-Dihydroxy-L-Phenylalanine (18F-DOPA), Produced by a New Nucleophilic Substitution Approach, Compared With Carrier-Added ${ }^{18}$ F-L-DOPA, Prepared by Conventional Electrophilic Substitution. J. Nucl. Med. 2014, 56, 106-112. [CrossRef] [PubMed] 
83. Maisonial, A.; Serre, A.; Ouadi, A.; Schmitt, S.; Canitrot, D.; Léal, F.; Miot-Noirault, E.; Brasse, D.; Marchand, P.; Chezal, J.M. Base/Cryptand/Metal-Free Automated Nucleophilic Radiofluorination of $\left[{ }^{18} \mathrm{~F}\right]$ FDOPA from Iodonium Salts: Importance of Hydrogen Carbonate Counterion. Eur. J. Org. Chem. 2018, 2018, 7058-7065. [CrossRef]

84. Krasikova, R.N. Nucleophilic Synthesis of 6-L-[ ${ }^{18}$ F]FDOPA. Is Copper-Mediated Radiofluorination the Answer? Molecules 2020, 25, 4365. [CrossRef] [PubMed]

85. Orlovskaya, V.V.; Modemann, D.J.; Kuznetsova, O.F.; Fedorova, O.S.; Urusova, E.A.; Kolks, N.; Neumaier, B.; Krasikova, R.N.; Zlatopolskiy, B.D. Alcohol-Supported Cu-Mediated 18F-Fluorination of Iodonium Salts under "Minimalist" Conditions. Molecules 2019, 24, 3197. [CrossRef] [PubMed]

86. Tredwell, M.; Preshlock, S.M.; Taylor, N.J.; Gruber, S.; Huiban, M.; Passchier, J.; Mercier, J.; Génicot, C.; Gouverneur, V. A General Copper-Mediated Nucleophilic ${ }^{18}$ F Fluorination of Arenes. Angew. Chem. Int. Ed. 2014, 53, 7751-7755. [CrossRef] [PubMed]

87. Ye, Y.; Schimler, S.D.; Hanley, P.S.; Sanford, M.S. Cu(OTf $)_{2}$-Mediated Fluorination of Aryltrifluoroborates with Potassium Fluoride. J. Am. Chem. Soc. 2013, 135, 16292-16295. [CrossRef] [PubMed]

88. Mossine, A.V.; Brooks, A.F.; Makaravage, K.J.; Miller, J.M.; Ichiishi, N.; Sanford, M.S.; Scott, P.J.H. Synthesis of [ ${ }^{18}$ F]Arenes via the Copper-Mediated $\left[{ }^{18}\right.$ F]Fluorination of Boronic Acids. Org. Lett. 2015, 17, 5780-5783. [CrossRef]

89. Makaravage, K.J.; Brooks, A.F.; Mossine, A.V.; Sanford, M.S.; Scott, P.J.H. Copper-Mediated Radiofluorination of Arylstannanes with [ ${ }^{18}$ F]KF. Org. Lett. 2016, 18, 5440-5443. [CrossRef] [PubMed]

90. Preshlock, S.; Calderwood, S.; Verhoog, S.; Tredwell, M.; Huiban, M.; Hienzsch, A.; Gruber, S.; Wilson, T.C.; Taylor, N.J.; Cailly, T.; et al. Enhanced copper-mediated ${ }^{18} \mathrm{~F}$-fluorination of aryl boronic esters provides eight radiotracers for PET applications. Chem. Commun. 2016, 52, 8361-8364. [CrossRef]

91. Zischler, J.; Kolks, N.; Modemann, D.; Neumaier, B.; Zlatopolskiy, B.D. Alcohol-Enhanced Cu-Mediated Radiofluorination. Chem. Eur. J. 2017, 23, 3251-3256. [CrossRef]

92. Orlovskaya, V.; Fedorova, O.; Kuznetsova, O.; Krasikova, R. Cu-Mediated Radiofluorination of Aryl Pinacolboronate Esters: Alcohols as Solvents with Application to 6-L-[ ${ }^{18}$ F]FDOPA Synthesis. Eur. J. Org. Chem. 2020, 45, 7079-7086. [CrossRef]

93. Antuganov, D.; Zykov, M.; Timofeev, V.; Timofeeva, K.; Antuganova, Y.; Fedorova, O.; Orlovskaya, V.; Krasikova, R. Coppermediated radiofluorination of aryl pinacolboronate esters: A straightforward protocol using pyridinium sulfonates. Eur. J. Org. Chem. 2019, 2019, 918-922. [CrossRef]

94. Zhang, X.; Basuli, F.; Swenson, R.E. An azeotropic drying-free approach for copper-mediated radiofluorination without addition of base. J. Label. Comp. Radiopharm. 2019, 62, 139-145. [CrossRef]

95. Mossine, A.V.; Brooks, A.F.; Ichiishi, N.; Makaravage, K.J.; Sanford, M.S.; Scott, P.J. Development of Customized [ ${ }^{18}$ F]Fluoride Elution Techniques for the Enhancement of Copper-Mediated Late-Stage Radiofuorination. Sci. Rep. 2017, 7, 233. [CrossRef] [PubMed]

96. Zlatopolskiy, B.D.; Zischler, J.; Schäfer, D.; Urusova, E.A.; Guliyev, M.; Bannykh, O.; Endepols, H.; Neumaier, B. Discovery of 7-[ ${ }^{18}$ F]Fluorotryptophan as a Novel Positron Emission Tomography (PET) Probe for the Visualization of Tryptophan Metabolism in Vivo. Med. Chem. 2018, 61, 189-206. [CrossRef] [PubMed]

97. Zlatopolskiy, B.D.; Neumaier, F.; Rüngeler, T.; Drewes, B.; Kolks, N.; Neumaier, B. Preparation of a First ${ }^{18}$ F-Labeled Agonist for $\mathrm{M}_{1}$ Muscarinic Acetylcholine Receptors. Molecules 2020, 25, 2880. [CrossRef] [PubMed]

98. Zlatopolskiy, B.D.; Endepols, H.; Krasikova, R.N.; Fedorova, O.S.; Neumaier, B. ${ }^{11}$ C- and ${ }^{18}$ F-labelled tryptophans as PET-tracers for imaging of altered tryptophan metabolism in age-associated disorders. Russ. Chem. Rev. 2020, 89, 879-896. [CrossRef]

99. Craig, A.; Kolks, N.; Urusova, E.A.; Zischler, J.; Brugger, M.; Endepols, H.; Neumaier, B.; Zlatopolskiy, B.D. Preparation of labeled aromatic amino acids via late-stage ${ }^{18}$ F-fluorination of chiral nickel and copper complexes. Chem. Commun. 2020, 56, 9505-9508. [CrossRef] [PubMed]

100. Orlovskaya, V.V.; Craig, A.S.; Fedorova, O.S.; Kuznetsova, O.F.; Neumaier, B.; Krasikova, R.N.; Zlatopolskiy, B.D. Production of 6-L- $\left[{ }^{18} \mathrm{~F}\right]$ Fluoro- $m$-tyrosine in an Automated Synthesis Module for ${ }^{11} \mathrm{C}$-Labeling. Molecules 2021, 26, 5550. [CrossRef]

101. Bernard-Gauthier, V.; Mossine, A.V.; Mahringer, A.; Aliaga, A.; Bailey, J.J.; Shao, X.; Stauff, J.; Arteaga, J.; Sherman, P.; Grand'Maison, M.; et al. Identification of $\left[{ }^{18}\right.$ F]TRACK, a Fluorine-18-Labeled Tropomyosin Receptor Kinase (Trk) Inhibitor for PET Imaging. J. Med. Chem. 2018, 61, 1737-1743. [CrossRef]

102. Yuan, G.; Shoup, T.M.; Moon, S.H.; Brownell, A.L. A concise method for fully automated radiosyntheses of $\left[{ }^{18} \mathrm{~F}\right] J N J-46356479$ and $\left[{ }^{18}\right.$ F]FITM via Cu-mediated ${ }^{18}$ F-fluorination of organoboranes. RSC Adv. 2020, 10, 25223-25227. [CrossRef]

103. Mossine, A.V.; Tanzey, S.S.; Brooks, A.F.; Makaravage, K.J.; Ichiishi, N.; Miller, J.M.; Henderson, B.D.; Skaddan, M.B.; Sanford, M.S.; Scott, P.J.H. One-pot synthesis of high molar activity 6- $\left[{ }^{18} \mathrm{~F}\right]$ fluoro-l-DOPA by Cu-mediated fluorination of a BPin precursor. Org. Biomol. Chem. 2019, 17, 8701-8705. [CrossRef] 